\title{
Density Functional Study of Structures and Electron Affinities of $\mathrm{BrO}_{4} \mathrm{~F} / \mathrm{BrO}_{4} \mathrm{~F}^{-}$
}

\author{
Liangfa Gong, Jieming Xiong *, Xinmin Wu, Chuansong Qi, Wei Li and Wenli Guo \\ College of Chemical Engineering, Beijing Institute of Petro-Chemical Technology, Beijing 102617, \\ China; E-Mails: gongliangfa@bipt.edu.cn (L.G.); wuxinmin@bipt.edu.cn (X.W.); \\ qichuansong@bipt.edu.cn (C.Q.); liwei77@bipt.edu.cn (W.L.)
}

* Author to whom correspondence should be addressed; E-Mail: xiong_jm@126.com; Tel. +86-10-8129-2131; Fax: +86-10-8129-2131

Received: 13 May 2009; in revised form: 29 June 2009 / Accepted: 6 July 2009 /

Published: 8 July 2009

\begin{abstract}
The structures, electron affinities and bond dissociation energies of $\mathrm{BrO}_{4} \mathrm{~F} / \mathrm{BrO}_{4} \mathrm{~F}^{-}$species have been investigated with five density functional theory (DFT) methods with $\mathrm{DZP}++$ basis sets. The planar $\mathrm{F}-\mathrm{Br} \ldots \mathrm{O}_{2} \ldots \mathrm{O}_{2}$ complexes possess ${ }^{3} \mathrm{~A}^{\prime}$ electronic state for neutral molecule and ${ }^{4} \mathrm{~A}^{\prime}$ state for the corresponding anion. Three types of the neutral-anion energy separations are the adiabatic electron affinity $\left(\mathrm{EA}_{\mathrm{ad}}\right)$, the vertical electron affinity $\left(\mathrm{EA}_{\mathrm{ver}}\right)$, and the vertical detachment energy (VDE). The $\mathrm{EA}_{\mathrm{ad}}$ value predicted by B3LYP method is $4.52 \mathrm{eV}$. The bond dissociation energies $\mathrm{D}_{\mathrm{e}}\left(\mathrm{BrO}_{4} \mathrm{~F}\right.$ $\left.\rightarrow \mathrm{BrO}_{4-\mathrm{m}} \mathrm{F}+\mathrm{O}_{\mathrm{m}}\right)(\mathrm{m}=1-4)$ and $\mathrm{D}_{\mathrm{e}}^{-}\left(\mathrm{BrO}_{4} \mathrm{~F}^{-} \rightarrow \mathrm{BrO}_{4-\mathrm{m}} \mathrm{F}^{-}+\mathrm{O}_{\mathrm{m}}\right.$ and $\mathrm{BrO}_{4} \mathrm{~F}^{-} \rightarrow \mathrm{BrO}_{4-\mathrm{m}} \mathrm{F}+$ $\left.\mathrm{O}_{\mathrm{m}}{ }^{-}\right)$are predicted. The adiabatic electron affinities $\left(\mathrm{EA}_{\mathrm{ad}}\right)$ were predicted to be $4.52 \mathrm{eV}$ for F-Br... $\mathrm{O}_{2} \ldots \mathrm{O}_{2}\left({ }^{3} \mathrm{~A}^{\prime} \leftarrow{ }^{4} \mathrm{~A}^{\prime}\right)$ (B3LYP method).
\end{abstract}

Keywords: density functional theory; bromine fluorine oxides; DFT-based descriptors; EA

\section{Introduction}

In recent days, density functional theory (DFT) has been enjoying tremendous success in electronic structure calculations for molecules and solids alike [1-8]. The DFT methods are able to describe the electronic structure of these systems with accuracies comparable to traditional correlated molecular 
orbital methods at a decreased computational cost. Furthermore these techniques are observed to assign more bonding character to the Lewis system in which the nucleophilic reaction occurs [9]. The DFT-based global and local properties (namely, DFT descriptors), such as Fukui functions, global and local hardness or softness $[10,11]$, have already been used for reliable predictions in various types of electrophilic and nucleophilic reactions on a diversity of material structures [1-9,12-16]. In some sense, the DFT-descriptors provide us with more rigorous alternatives than the classical frontier orbital analysis. Chatterjee's group have already used the DFT-descriptors for predictions in electrophilic and nucleophilic reactions in the case of zeolites and clay materials with or without solvent environment [1-7].

On the other hand, the bromine, chlorine, and fluorine oxides are known to be important in lower stratospheric ozone depletion, and have been the subjects of intense studies in recent years [17-26, and references cited therein]. Relevant bromine oxide fluorides, represent intriguing ternary molecules involving covalent bond between highly electronegative atoms, possessing a large number of unpaired electrons, resulting in strong lone pair-lone pair repulsions. Therefore, the hypervalent structures of these species could be characterized. As early as 1972, Johnson et al. [27] reported the thermodynamic properties of $\mathrm{Br}(\mathrm{VII}) \mathrm{FBrO}_{3}$ species. In 1976, Appelman et al. [28] characterized the molecular structure of gaseous perbromyl fluoride $\left(\mathrm{FBrO}_{3}\right)$, and Gillespie and Spekkens [29] prepared and characterized potassium difluorodioxobromate $\left(\mathrm{BrO}_{2} \mathrm{~F}_{2}^{-}\right)$and tetrafluoro-oxobromate $\left(\mathrm{BrOF}_{4}^{-}\right)$. In 1978, Christe et al. [30] reported the vibrational frequencies and assignment of $\mathrm{BrOF}_{3}$. In 2005, Lehmann et al. [31] reported synthesis and characterization of salts containing the bromine (VII) $\mathrm{BrO}_{3} \mathrm{~F}_{2}{ }^{-}$anion; last year, Lehmann et al. [32] also reported the characterization of $\mathrm{BrO}_{3} \mathrm{~F}$ and $\mathrm{ClO}_{3} \mathrm{~F}$ to $\left[\mathrm{XO}_{2}\right]\left[\mathrm{SbF}_{6}\right](\mathrm{X}=\mathrm{Cl}, \mathrm{Br})$ by single crystal $\mathrm{X}$-ray diffraction, raman spectroscopy, and computational methods. The results showed that of a few computational methods, the DFT functional, B3LYP in combination with the aug-cc-pVTZ basis set, and the QCISD and $\operatorname{CSS}(\mathrm{T})$ calculations provided the most reliable correlation with the experimental geometry and vibrational frequencies of $\mathrm{BrO}_{2}^{+}[33]$ and likely provide reliable estimates of the geometric parameters and vibrational frequencies of $\mathrm{BrO}_{3}{ }^{+}$, as well as benchmarks for calculations involving bromine fluoride and oxide fluoride species [33]. Correspondingly, the density functional theory (DFT) in conjunction with DZP++ basis set has also localized these Br-hypervalent ternary structures to be minimum on the potential energy surfaces (PES) $[34,35]$. The planar/lineaer FBrO/FBrO-, pseudo-trigonal bipyramid $\mathrm{F}\left(\mathrm{F}_{2}\right) \mathrm{Br}=\mathrm{O}\left(\mathrm{C}_{\mathrm{s}}\right.$ symmetric $)$ [34] and [F-(:BrO 2$)-F]^{-}\left(\mathrm{C}_{2 \mathrm{v}}\right)$ anionic [29], and quasi-octahedral $\left(\mathrm{OBr}-\mathrm{F}_{4}\right)^{-}\left(\mathrm{C}_{4 \mathrm{v}}\right)$ [34,29] $\mathrm{Br}(\mathrm{V})$ structures have been found to be the lowest-lying isomers. However, the hypervalent $\mathrm{FBrO}_{2}, \mathrm{FBrO}_{3}$ [35], and their corresponding anionic isomers are local minima on the PES. These DFT methods, especially the hybrid DFT methods (BHLYP and B3LYP) are reliable to predict the bond lengths and bond angles [32]. Besides the rich fluoride chemistry of the III and V oxidation states of $\mathrm{Br}$ oxides, the fluoride ion transfer reactions containing Br(VII) are scarce and have only been established by the syntheses of the ternary bromine oxide fluorides, $\mathrm{BrO}_{3} \mathrm{~F}_{2}^{-}$[31]. In this work, we report the systemic theoretical investigation of the similar $\mathrm{BrO}_{4} \mathrm{~F} / \mathrm{BrO}_{4} \mathrm{~F}^{-}$species, which may be of importance in atmospheric chemistry.

DFT/DZP++ scheme has been shown to be successful in prediction of electron affinities (EAs) of many species, such as $\mathrm{BrOF}_{\mathrm{n}} / \mathrm{BrOF}_{\mathrm{n}}^{-}, \mathrm{FBrO}_{2} / \mathrm{FBrO}_{3}, \mathrm{Br}_{2} \mathrm{O}_{\mathrm{n}} / \mathrm{Br}_{2} \mathrm{O}_{\mathrm{n}}{ }^{-}, \mathrm{BrClF}_{\mathrm{n}} / \mathrm{BrClF}_{\mathrm{n}}$ and $\mathrm{SF}_{5} \mathrm{O}_{\mathrm{n}} / \mathrm{SF}_{5} \mathrm{O}_{\mathrm{n}}{ }^{-}$ $(n=1-3)$ species [34-38]. These studies and others have demonstrated that the DFT/DZP++ methods 
can predict electron affinities (EAs) in a good accuracy [39]. In addition, these methods are reliable for the geometry optimization of the neutral radicals and their anion.

The aim of the present work is to apply five DFT methods to predict the electron affinities of ternary bromine oxide fluoride, $\mathrm{BrO}_{4} \mathrm{~F}$, as well as the equilibrium geometries, harmonic vibrational frequencies, and bond dissociation energies. Four forms of the electron affinities are calculated, evaluated as the neutral-anion energy separations in the following manners. The adiabatic electron affinities $\left(\mathrm{EA}_{\mathrm{ad}}\right)$ are determined by, $\mathrm{EA}_{\mathrm{ad}}=\mathrm{E}_{\text {(optimized neutral })}-\mathrm{E}_{\text {(optimized anion), zero-point corrected }}$ adiabatic electron affinities $\left(\mathrm{EA}_{\text {zero }}\right)$ are determined by, $\mathrm{EA}_{\text {zero }}=\mathrm{E}_{\text {(zero-point corrected neutral) }}-\mathrm{E}_{\text {(zero-point }}$ corrected anion), the vertical electron affinities $\left(\mathrm{EA}_{\mathrm{vert}}\right)$ by, $\mathrm{EA}_{\mathrm{vert}}=\boldsymbol{E}_{\text {(optimized neutral) }}-\boldsymbol{E}_{\text {(anion at optimized neutral }}$ geometry), and the vertical detachment energies (VDE) of the anion by, $\mathrm{VDE}=\boldsymbol{E}_{\text {(neutral at optimized anion geometry) }}$ - $E_{\text {(optimized anion). }}$ The DFT descriptors, such as Fukui functions, global and local hardness or softness $[10,11]$, also have been used for the reliable predictions in the stability of $\mathrm{BrO}_{4} \mathrm{~F}$ isomers.

\section{Theory}

Just like Chatterjee et al. [1-5] rationalized the structure-property relationship in different clays and observed that the hydroxyl groups present in the clay structure play a crucial role in the catalytic activity. We have explored the role of $\mathrm{O}$ and $\mathrm{F}$ atoms on the structure and properties of different bromine oxygen fluoides [34,35].

The hard-soft acid-base (HSAB) principles categorize the interaction between acids and bases in terms of global softness. Pearson proposed the global HSAB principle [40]. The global hardness was the second derivative of energy with respect to the number of electrons at constant temperature and external potential, which includes the nuclear field. The nonchemical meaning of the word "hardness" is resistance to deformation or change.

The global softness is the inverse of this. Pearson also pointed out a principle of maximum hardness (PMH) [41], which stated that, for a constant external potential, the system with the maximum global hardness is the most stable.

DFT-based local properties, like Fukui functions and local softness [10], have already been used for reliable predictions of electrophilic and nucleophilic reactions [1-8]. Generally, compared to a gasphase calculation, the solvent environment alters the charge distribution of a molecule. There is an increase in the dipole moment of molecules such as water and $\mathrm{BrF}$, which enhances the intrinsic reactivity of polar molecules toward nucleophilic and electrophilic attack [15]. Our aim in the current work is to explore the role of $\mathrm{O}_{\mathrm{n}}$ chain in the structure and bonding of $\mathrm{BrO}_{4} \mathrm{~F}$ species. DFT-based local descriptors have been used for calculating the reactivity index within the helm of the HSAB principle [11-15]. It is used to determine the possible correlation between $\mathrm{BrO}_{4} \mathrm{~F}$ isomers.

In density functional theory, hardness $(\eta)[40]$ is defined as:

$$
\eta=(1 / 2)\left(\partial^{2} E / \partial N^{2}\right) v(r)=(1 / 2)(\partial \mu / \partial N)_{v}
$$

where $E$ is the total energy, $N$ is the number of electrons of the chemical species, and $\mu$ is the chemical potential.

The global softness, $\mathrm{S}$, is defined as the inverse of the global hardness, $\eta$ : 


$$
S=\frac{1}{2 \eta}=(\partial N / \partial \mu)_{v}
$$

Using the finite difference approximation, $S$ can be approximated as:

$$
S=1 /(I E-E A)
$$

where $I E$ and $E A$ are the first ionization energy and electron affinity of the molecule, respectively.

The Fukui function $f(r)$ is defined by [10]:

$$
f(r)=[\delta \mu / \delta v(r)]_{N}=[\partial \rho(r) / \partial N]_{v}
$$

The function $f$ is thus a local quantity, which has different values at different points in the species, $N$ is the total number of electrons, $\mu$ is the chemical potential, and $v$ is the potential acting on an electron due to all nuclei present. Since $\rho(r)$ as a function of $N$ has slope discontinuities, equation 1 provides the following three reaction indices [10]:

$$
\begin{aligned}
& f^{-}(r)=[\partial \rho(r) / \partial N]_{v}^{-} \quad \text { (governing electrophilic attack) } \\
& f^{+}(r)=[\partial \rho(r) / \partial N]_{v}^{+} \quad \text { (governing nucleophilic attack) } \\
& f^{0}(r)=(1 / 2)\left[f^{+}(r)+f^{-}(r)\right] \quad \text { (for radical attack) }
\end{aligned}
$$

In a finite difference approximation, the condensed Fukui function [16] of an atom, say $x$, in a molecule with $N$ electrons is defined as:

$$
\begin{gathered}
f_{x}^{+}=\left[q_{x}(N+1)-q_{x}(N)\right] \quad \text { (for nucleophilic attack) } \\
f_{x}^{-}=\left[q_{x}(N)-q_{x}(N-1)\right] \quad(\text { for electrophilic attack) } \\
f_{x}^{0}=\left[q_{x}(N+1)-q_{x}(N-1)\right] / 2 \quad(\text { for radical attack) }
\end{gathered}
$$

where $q_{\mathrm{x}}$ is the electronic population of atom $\mathrm{x}$ in a molecule. The local softness $s(r)$ can be defined as:

$$
s(r)=(\delta \rho(r) / \delta \mu)_{v}
$$

Equation(3) can also be written as:

$$
s(r)=[\partial \rho(r) / \partial N]_{v}[\partial N / \partial \mu]_{v}=f(r) S
$$

Thus, local softness contains the same information as the Fukui function $f(r)$ plus additional information about the total molecular softness, which is related to the global reactivity with respect to a reaction partner, as stated in the HSAB principle. Atomic softness values can easily be calculated by using equation 4 , namely:

$$
\begin{gathered}
s_{x}^{+}(r)=\left[q_{x}(N+1)-q_{x}(N)\right] S \\
s_{x}^{-}(r)=\left[q_{x}(N)-q_{x}(N-1)\right] S \\
s_{x}^{0}(r)=S\left[q_{x}(N+1)-q_{x}(N-1)\right] / 2
\end{gathered}
$$




\section{Methodology}

The five different DFT exchange-correlation functionals employed in this work range from generalized gradient approximation (GGA) [BLYP, BP86] to hybrid-GGA [BHLYP, B3P86 , and B3LYP]. These hybrid Hartree-Fock/density functionals include: (a) Becke's half and half HF/DFT hybrid exchange functional (BH) [42] with the Lee, Yang, and Parr correlation functional (LYP) [43] (BHLYP); (b) Becke's three parameter functional [44] (B3) plus Perdew's correlation functional (P86) [45] (B3P86); (c) B3 combined with LYP functionals (B3LYP) [44,43]; (d) incorporation of Becke's 1988 exchange functional (B) [46] with Perdew's correlation functional (P86) (BP86); (e) B along with LYP (BLYP) $[46,43]$. The standard double- $\zeta$ plus polarization (DZP) basis set augmented with diffuse functions (DZP++) were utilized. The basis set for bromine was comprised of Ahlrichs' standard double-spd set plus a set of $d$-type polarization functions $\left[\alpha_{d}(\mathrm{Br})=0.389\right.$ ] [47] plus diffuse functions $\left[\alpha_{s}(\mathrm{Br})=0.0469\right.$ and $\left.\alpha_{p}(\mathrm{Br})=0.0465\right]$. For oxygen and fluorine, the basis sets were composed of the standard Huzinaga-Dunning [48,49] double- $\zeta$ set plus one set of polarization functions $\left[\alpha_{d}(\mathrm{O})=0.85, \alpha_{d}(\mathrm{~F})=1.00\right]$ augmented with one set of diffuse functions $\left[\alpha_{s}(\mathrm{O})=0.08227\right.$, $\alpha_{p}(\mathrm{O})=0.06508$, and $\left.\alpha_{s}(\mathrm{~F})=0.1049, \alpha_{p}(\mathrm{~F})=0.0826\right]$. The final contracted basis sets are thus designated as $\mathrm{Br}(15 \mathrm{~s} 12 \mathrm{p} 6 \mathrm{~d} / 9 \mathrm{~s} 7 \mathrm{p} 3 \mathrm{~d}), \mathrm{O}(10 \mathrm{~s} 6 \mathrm{p} 1 \mathrm{~d} / 5 \mathrm{~s} 3 \mathrm{p} 1 \mathrm{~d})$, and $\mathrm{F}(10 \mathrm{~s} 6 \mathrm{p} 1 \mathrm{~d} / 5 \mathrm{~s} 3 \mathrm{p} 1 \mathrm{~d})$. All of the molecular structures and the electron affinities have been determined using the Gaussian 03 program suite [50]. The fine integration grid (99 590) was used. All stationary point geometries were characterized by the evaluation of their harmonic vibrational frequencies at the five different levels of theory. Unless otherwise reported, the geometries in figures were found to be minima after determining the harmonic vibrational frequencies via analytical second derivatives for the corresponding stationary point structures for each function.

Besides the electron affinities, the bond dissociation energies for $\mathrm{BrO}_{4} \mathrm{~F} / \mathrm{BrO}_{4} \mathrm{~F}^{-}$are also determined as the difference in total energies in the following manners:

The bond dissociation energies for the neutrals refer to the reactions:

$$
\mathrm{BrO}_{4} \mathrm{~F} \rightarrow \mathrm{BrO}_{3} \mathrm{~F}+\mathrm{O}, \mathrm{BrO}_{4} \mathrm{~F} \rightarrow \mathrm{BrO}_{2} \mathrm{~F}+\mathrm{O}_{2}, \mathrm{BrO}_{4} \mathrm{~F} \rightarrow \mathrm{BrOF}+\mathrm{O}_{3},
$$

The bond dissociation energies for the anions refer to the reactions:

$$
\begin{gathered}
\mathrm{BrO}_{4} \mathrm{~F}^{-} \rightarrow \mathrm{BrO}_{3} \mathrm{~F}^{-}+\mathrm{O}, \mathrm{BrO}_{4} \mathrm{~F}^{-} \rightarrow \mathrm{BrO}_{2} \mathrm{~F}^{-}+\mathrm{O}_{2}, \mathrm{BrO}_{4} \mathrm{~F}^{-} \rightarrow \mathrm{BrOF}^{-}+\mathrm{O}_{3}, \\
\mathrm{BrO}_{4} \mathrm{~F}^{-} \rightarrow \mathrm{BrO}_{3} \mathrm{~F}+\mathrm{O}^{-}, \mathrm{BrO}_{4} \mathrm{~F}^{-} \rightarrow \mathrm{BrO}_{2} \mathrm{~F}+\mathrm{O}_{2}^{-}, \mathrm{BrO}_{4} \mathrm{~F}^{-} \rightarrow \mathrm{BrOF}+\mathrm{O}_{3}^{-}
\end{gathered}
$$

The natrural bond orbital (NBO) analysis [51] was carried out at the B3LYP/DZP++ level for some species, corresponding Wiberg bond index (WBI) and atomic charges are obtained. Unless otherwise stated, we use the B3LYP result for molecular structures and energetics. The counterpoise (CP) method [52] was used to correct the basis set superposition error (BSSE) [7,53] using the BoysBernardi method in the calculation of the binding energy for the current basis. For these complexes of Lewis species, the single point calculations of the cation and anion of each molecule at the optimized geometry of the neutral molecule were also carried out to evaluate Fukui functions, global and local softness [10]. The condensed Fukui function and atomic softness were evaluated using equations 3 and 6 in Section 2. Theory, respectively. The gross atomic charges were evaluated using the technique of 
Mulliken charges, due to the $\mathrm{Br}$ atomic charge can hardly be evaluated by using the technique of electrostatic potential (ESP) driven charges.

\section{Results and Discussion}

With the present five DFT methods, the optimized O-F bond length for single OF molecule ranges from $1.331 \AA$ (BHLYP) to $1.385 \AA$ (BLYP) (not shown). The trend of bond lengths predicted for O-F is BHLYP $<\mathrm{B} 3 \mathrm{P} 86<\mathrm{B} 3 \mathrm{LYP}<\mathrm{BP} 86<\mathrm{BLYP}$. The DZP++ B3LYP method gives the result closest to the experimental O-F bond length $\left(\mathrm{r}_{\mathrm{e}}\right)$ of $1.3541 \AA$, obtained from Raman spectroscopy [18 and references cited therein]. The B3LYP method also obtain the best prediction result for dissociation energy $\left(D_{e}\right)$ of OF [23] and BrO [21]. For a discussion of the reliability of B3LYP thermochemistry, see the recent work of Boese, Martin, and Handy [54]. Therefore, in the following discussion, unless otherwise stated, we use the B3LYP result for molecular structures and energetics.

For neutral $\mathrm{BrO}_{4} \mathrm{~F}$ species, the molecular chain $\mathrm{FBr}$...OO...OO structure with a terminal $\mathrm{F}-\mathrm{Br}$ moiety connected by OO...OO chain lies the lowest energetically. This structure in its ${ }^{5} \mathrm{~A}^{\prime}$ state (all of the five DFT methods) or ${ }^{3} \mathrm{~A}^{\prime}$ state (both BP86 and BLYP pure DFT methods) corresponds a very loose van der Waals complex between $\mathrm{BrF}$...OO and $\mathrm{O}_{2}$, possessing a binding energy of about zero and the very long $\mathrm{Br} . . \mathrm{O}\left(2.719-3.004 \AA\right.$ in ${ }^{5} \mathrm{~A}^{\prime}$ state and 2.618, $2.719 \AA$ in ${ }^{3} \mathrm{~A}^{\prime}$ state) and $(\mathrm{O}) \mathrm{O} \cdots \mathrm{O}(\mathrm{O})$ (5.220-7.095 $\AA$ in ${ }^{5} \mathrm{~A}^{\prime}$ state, and 5.746, 6.014 $\AA$ in ${ }^{3} \mathrm{~A}^{\prime}$ state) distances (not shown). It is favorable to dissociate into $\mathrm{BrF}+2 \mathrm{O}_{2}\left({ }^{3} \Sigma_{\mathrm{g}}{ }^{-}\right)$or $\mathrm{BrF}+\mathrm{O}_{2}\left({ }^{1} \Delta_{\mathrm{g}}\right)+\mathrm{O}_{2}\left({ }^{3} \Sigma_{\mathrm{g}}{ }^{-}\right)$.

The FBr...OO...OO structures in ${ }^{3} \mathrm{~A}^{\prime}$ state $\left(\mathbf{a}:{ }^{3} \mathrm{~A}^{\prime}\right)$ optimized by three hybrid DFT methods (BHLYP, B3P86 and B3LYP) and in ${ }^{1} \mathrm{~A}^{\prime}\left(\mathbf{b}:{ }^{1} \mathrm{~A}^{\prime}\right)$ (BHLYP) or ${ }^{1} \mathrm{~A}\left(\mathbf{b}:{ }^{1} \mathrm{~A}\right)$ state (with the rest four DFT methods) are reported in Figure 1. The optimized geometries for both $\mathrm{Br}$ - and F-terminal structures, including cis- and trans- $\mathrm{BrOO} \ldots$. OOF $\left(\mathbf{c}:{ }^{1} \mathrm{~A}\right.$ and $\left.\mathbf{d}:{ }^{1} \mathrm{~A}\right)$, and $\mathrm{BrOO}(\mathrm{O}) \ldots \mathrm{OF}\left(\mathbf{e}:{ }^{1} \mathrm{~A}\right)$, and those of $\mathrm{Br}-$ hypervalent structures, $\mathrm{O}_{2} \mathrm{Br}$...OOF (f: $\left.{ }^{1} \mathrm{~A}\right)$ and $\mathrm{FBrO}_{3} \ldots \mathrm{O}\left(\mathrm{g}: \mathrm{C}_{3 \mathrm{v}},{ }^{3} \mathrm{~A}_{1}\right)$ are also displayed in Figure 1. The optimized geometries for anionic $\mathrm{BrO}_{4} \mathrm{~F}^{-}$species, including $(\mathrm{FBr} \ldots \mathrm{OO})^{-} \ldots \mathrm{OO}\left(\mathbf{a a :}{ }^{4} \mathrm{~A}^{\prime}\right)$ chain, and $\left[\mathrm{FBr}\left(\mathrm{O}_{2}\right) \ldots \mathrm{OO}\right]^{-}\left(\mathbf{a b}:{ }^{2} \mathrm{~A}^{\prime}\right),\left(\mathrm{FO} \ldots \mathrm{BrO}_{3}\right)^{-}\left(\mathbf{a c}:{ }^{2} \mathrm{~A}^{\prime}\right)$ Br-hypervalent structures are shown in Figure 2 . They may represent an important intermediate in atmospheric reactions.

The calculated energies (Table 1) show that the FBr...OO...OO structure in its ${ }^{5} \mathrm{~A}^{\prime}$ state or its dissociation products $\left(\mathrm{FBr}{ }^{\cdots} \mathrm{OO}\left({ }^{3} \mathrm{~A}^{\prime \prime}\right)+\mathrm{O}_{2}\left({ }^{3} \Sigma_{\mathrm{g}}{ }^{-}\right)\right)$lies lower than the corresponding ${ }^{3} \mathrm{~A}^{\prime}(\mathbf{a})$ and ${ }^{1} \mathrm{~A}^{\prime}$ or ${ }^{1} \mathrm{~A}$ (b) states by about 33 and $60 \mathrm{kcal} / \mathrm{mol}$ respectively with the B3LYP method. This state also lies much lower than the cis-, trans- BrOO...OOF (c: ${ }^{1} \mathrm{~A}$ and $\left.\mathbf{d}:{ }^{1} \mathrm{~A}\right)$ and $\mathrm{BrOO}_{2} \ldots \mathrm{OF}\left(\mathbf{e}:{ }^{1} \mathrm{~A}\right)$ isomers by ca.64, 64, and $95 \mathrm{kcal} / \mathrm{mol}$ (Table 1) respectively (B3LYP). The $\mathrm{O}_{2} \mathrm{Br} \ldots \mathrm{OOF}\left(\mathbf{f}:{ }^{1} \mathrm{~A}\right)$ and $\mathrm{FBrO}_{3} \ldots \mathrm{O}(\mathrm{g}$ : $\mathrm{C}_{3 \mathrm{v}},{ }^{3} \mathrm{~A}_{1}$ ) Br-hypervalent structures lie much higher than the ${ }^{5} \mathrm{~A}^{\prime}$ state by ca. 78 and $130 \mathrm{kcal} / \mathrm{mol}$ (Table 1) respectively. With a few exceptions, the two pure DFT methods (BP86 and BLYP) predict much smaller relative energies and the bond dissociation energies than three hybrid DFT methods. All these discrepancies indicate that $\mathrm{BrO}_{4} \mathrm{~F}$ is a challenging target for DFT methods. 
Figure 1. Optimized geometries of neutral $\mathrm{BrO}_{4} \mathrm{~F}$ (a-g) with DFT/DZP++ approach (bond lengths in $\AA$, bond angles and dihedral angles in degrees). A: represents bond angle, D: represents torsion angle.
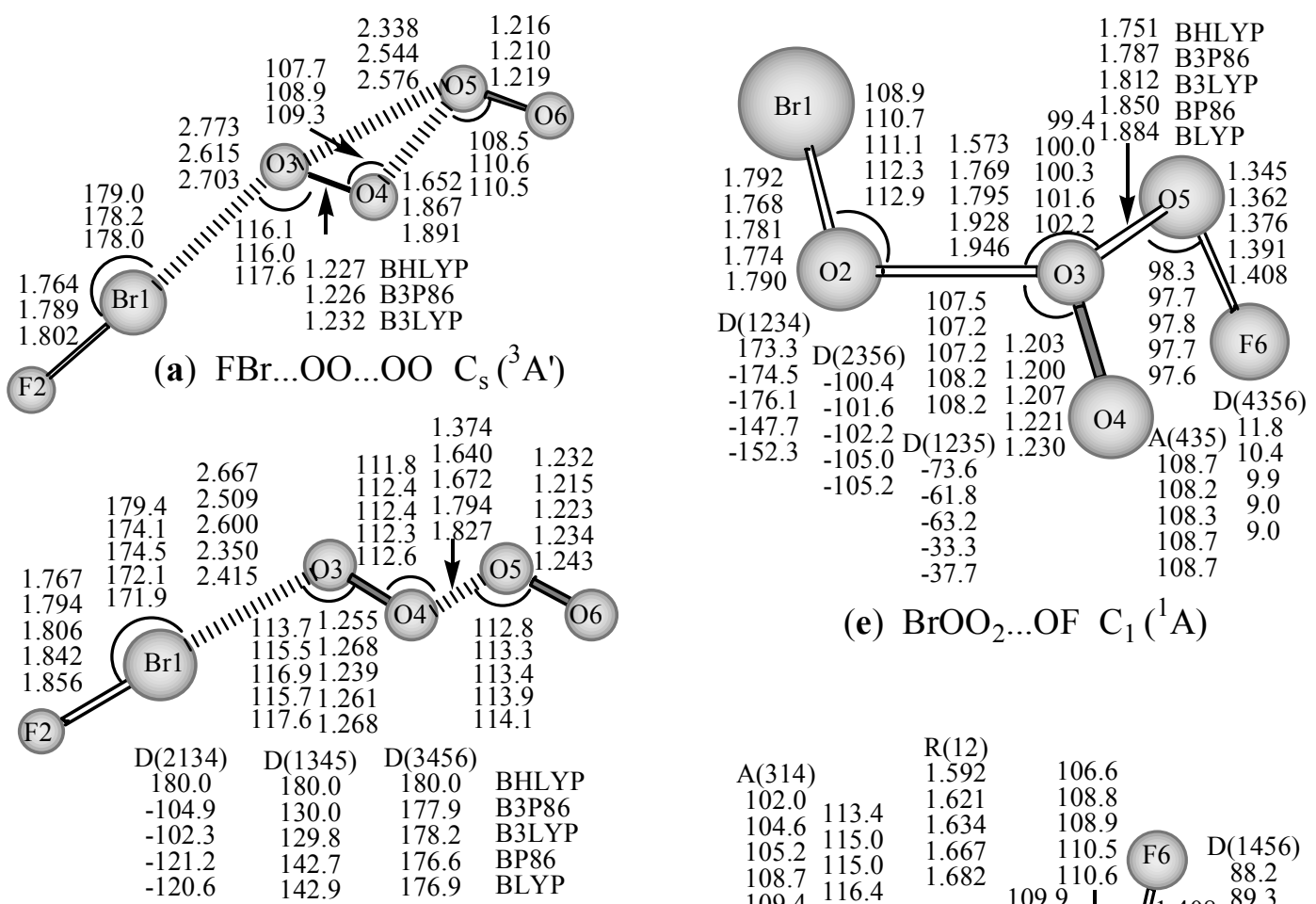

(e) $\mathrm{BrOO}_{2} \ldots \mathrm{OF} \mathrm{C}_{1}\left({ }^{1} \mathrm{~A}\right)$

(b) $\mathrm{FBr} \ldots \mathrm{OO} \ldots \mathrm{OOO} \mathrm{C}_{\mathrm{s}}, \mathrm{C}_{1}\left({ }^{1} \mathrm{~A}^{\prime},{ }^{1} \mathrm{~A}\right)$
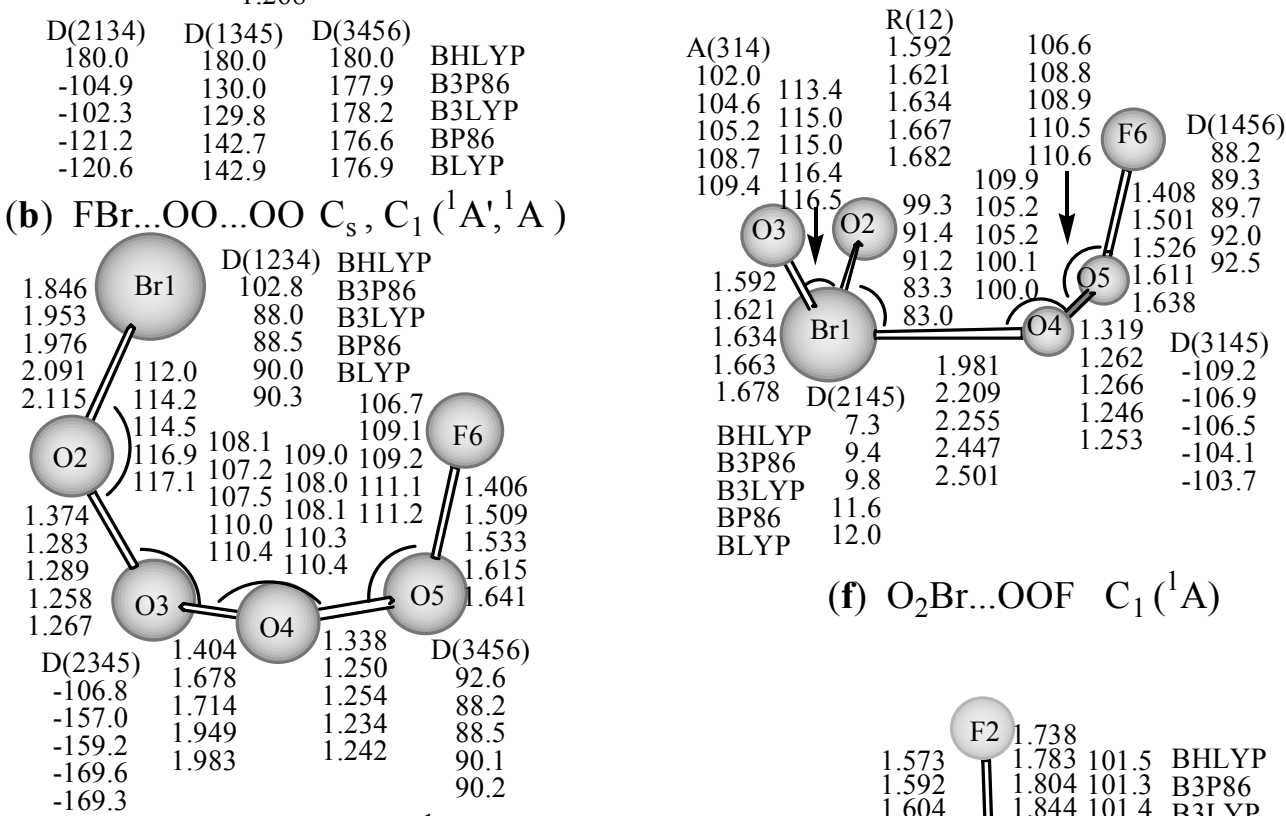

BLYP 12.0

$$
\text { (f) } \mathrm{O}_{2} \mathrm{Br} \ldots \text { OOF } \mathrm{C}_{1}\left({ }^{1} \mathrm{~A}\right)
$$

$$
\text { (c) BrOO...OOF } \mathrm{C}_{1}\left({ }^{1} \mathrm{~A}\right)
$$
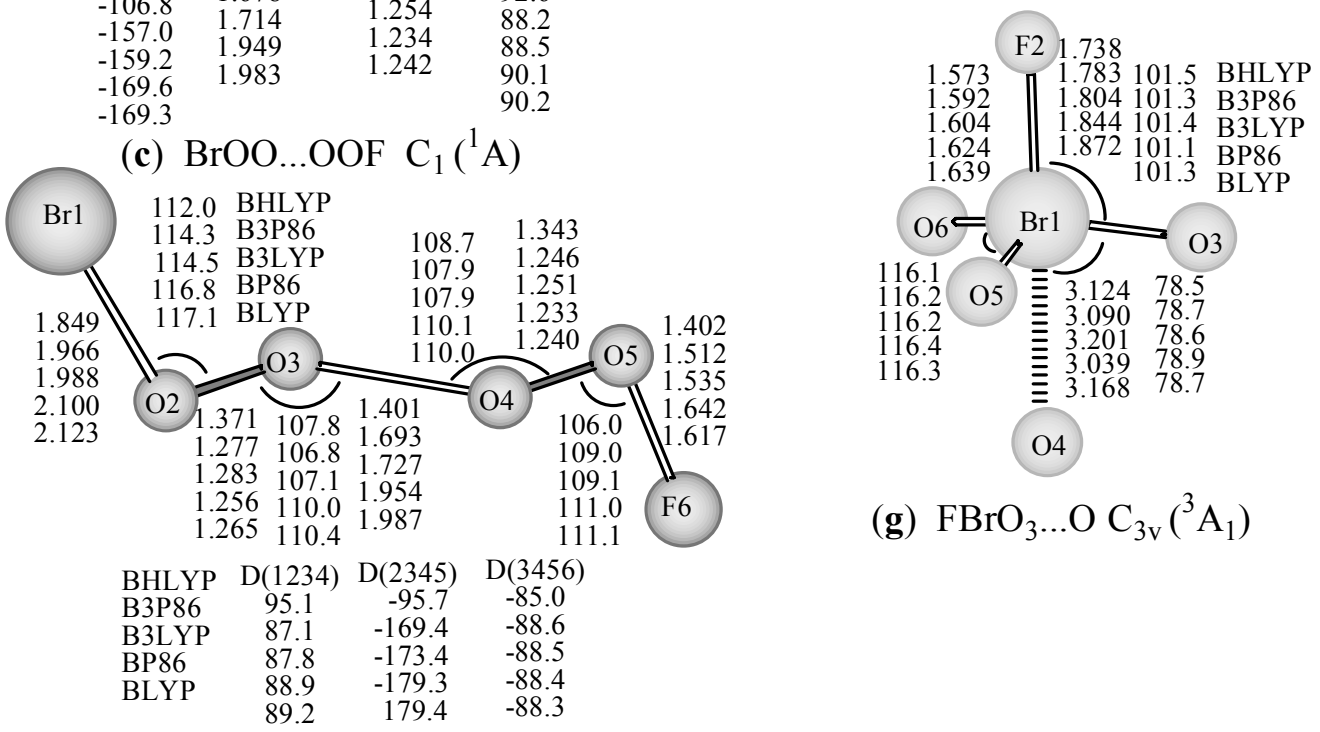

(g) $\mathrm{FBrO}_{3} \ldots \mathrm{O} \mathrm{C} \mathrm{C}_{3 \mathrm{v}}\left({ }^{3} \mathrm{~A}_{1}\right)$

(d) $\mathrm{BrOO} \ldots$ OOF $\mathrm{C}_{1}\left({ }^{1} \mathrm{~A}\right)$ 
Table 1. Relative energies in $\mathrm{kcal} \cdot \mathrm{mol}^{-1}$ for $\mathrm{BrO}_{4} \mathrm{~F}$ and its dissociation products species ${ }^{\mathrm{a}}$.

\begin{tabular}{|c|c|c|c|c|c|}
\hline & BHLYP & B3P86 & B3LYP & BP86 & BLYP \\
\hline 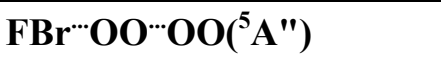 & 0.00 & 0.00 & 0.00 & 0.00 & 0.00 \\
\hline $\mathrm{FBr}{ }^{\cdots} \mathrm{OO}\left({ }^{3} \mathrm{~A}^{\prime \prime}\right)+\mathrm{O}_{2}\left({ }^{3} \Sigma_{\mathrm{g}}\right)^{\mathrm{c}}$ & 0.00 & 0.00 & 0.00 & 0.00 & 0.00 \\
\hline (a) $\left(\mathrm{C}_{\mathrm{s}},{ }^{3} \mathrm{~A}^{\prime}\right)$ & 56.08 & 31.27 & 33.03 & $--{ }^{b}$ & $--{ }^{b}$ \\
\hline (b) $\left(\mathrm{C}_{\mathrm{s}},{ }^{1} \mathrm{~A}^{\prime}\right)$ & 106.42 & 57.41 & 60.41 & 21.72 & 24.59 \\
\hline (c) $\left(\mathrm{C}_{1},{ }^{1} \mathrm{~A}\right)$ & 88.48 & 60.12 & 64.18 & 31.04 & 34.06 \\
\hline (d) $\left(\mathrm{C}_{1},{ }^{1} \mathrm{~A}\right)$ & 87.86 & 60.49 & 64.22 & 31.31 & 34.97 \\
\hline (e) $\left(C_{1},{ }^{1} A\right)$ & 136.87 & 91.65 & 94.63 & 60.82 & 62.94 \\
\hline (f) $\left(\mathrm{C}_{1},{ }^{1} \mathrm{~A}\right)$ & 112.37 & 72.28 & 78.33 & 43.66 & 48.31 \\
\hline (g) $\left(\mathrm{C}_{3 \mathrm{v}},{ }^{3} \mathrm{~A}_{1}\right)$ & 134.71 & 123.75 & 129.94 & 118.89 & 124.35 \\
\hline $\operatorname{FBr} \cdots \operatorname{OOO}\left({ }^{1} \mathrm{~A}^{\prime}\right)+\mathrm{O}^{\mathrm{c}}$ & 109.33 & 100.48 & 99.94 & 86.41 & 84.45 \\
\hline $\operatorname{FBr}{ }^{\cdots} \mathrm{OO}\left({ }^{3} A^{\prime \prime}\right)+\mathrm{O}_{2}\left({ }^{1} \Delta_{\mathrm{g}}\right)^{\mathrm{c}}$ & 43.19 & 39.65 & 39.15 & 38.02 & 38.90 \\
\hline $\operatorname{OBrF}\left({ }^{1} A^{\prime}\right)+O_{3}{ }^{c}$ & 100.63 & 67.12 & 70.73 & 47.95 & 51.31 \\
\hline
\end{tabular}

${ }^{a}$ corrected with ZPVE. ${ }^{b}$ At pure DFT methods (BP86 and BLYP), the triplet state of F-Br... $\mathrm{O}_{2} \ldots \mathrm{O}_{2}$ dissociated to $\mathrm{BrF}$ and $\mathrm{O}_{2} .{ }^{\mathrm{c}}$ The bond dissociation energies corrected with BSSE. ${ }^{\mathrm{d}} \mathrm{BrOO}$ is not converge with hybrid DFT methods.

As can be seen from Figure 1, for the FBr...OO...OO structure in its ${ }^{3} \mathrm{~A}^{\prime}$ state, the covalent bond lengths are predicted to be 1.764-1.802 $\AA$ for the Br-F bond, and 1.227-1.232 $\AA$ for interim O-O and 1.216-1.219 $\AA$ for the terminal O-O bond, and the complex bond distances are 2.615-2.773 $\AA$ for Br...O, and 1.652-1.891 $\AA$ for $(\mathrm{O}) \mathrm{O}{ }^{\cdots} \mathrm{O}(\mathrm{O})$ with three hybrid DFT methods. At the B3LYP level, Br-F bond length, the interim $\mathrm{O}-\mathrm{O}$ and terminal $\mathrm{O}-\mathrm{O}$ bond lengths in the ${ }^{3} \mathrm{~A}^{\prime}$ state (a in Figure 1) are 1.802, 1.232, and $1.219 \AA$ respectively, and $\mathrm{Br} . . \mathrm{O}$ or $(\mathrm{O}) \mathrm{O} \cdots \mathrm{O}(\mathrm{O})$ complex distance is 2.703 or $1.891 \AA$ respectively. These structure parameters are similar to those of the corresponding ${ }^{1} \mathrm{~A}^{\prime}$ state or ${ }^{1} \mathrm{~A}$ state of (b in Figure 1), in which, the Br-F bond distance, the interim O-O and terminal O-O bond lengths (b in Figure 1) are slightly elongated (1.806, 1.239, and $1.223 \AA$ respectively at B3LYP level), and $\mathrm{Br} . . \mathrm{O}$ or $(\mathrm{O}) \mathrm{O} \cdots \mathrm{O}(\mathrm{O})$ complex distance is significantly shortened (2.600 or $1.672 \AA$ respectively). The geometric and electronic structures show that the F-Br terminal moiety connected by OO...OO chain structure in ${ }^{3} \mathrm{~A}^{\prime}$ (hybrid DFT methods) or in singlet state may be viewed as a van der Waals complex between BrF moiety and OO-OO covalent-like chain respectively. NBO analyses (B3LYP) show that the ${ }^{3} \mathrm{~A}^{\prime}$ state possesses stronger single Br-F (WBI: 0.795 vs 0.781 ) and double O-O (WBI: 1.462 vs 1.436 for interim $\mathrm{O}-\mathrm{O} ; 1.524$ vs 1.519 for terminal $\mathrm{O}-\mathrm{O})$ bonds than the singlet state, and that the covalent OO-OO (WBI: 0.418 vs 0.717) and complex Br...O (WBI: 0.063 vs 0.089) bonds in ${ }^{3} \mathrm{~A}^{\prime}$ state are weaker than those in singlet state. Compared with the ${ }^{3} \mathrm{~A}^{\prime \prime}$ state of $\mathrm{FBr}$ ' $\mathrm{OO}$ [35], the $\mathrm{Br}-\mathrm{F}$ and interim $\mathrm{O}-\mathrm{O}$ bonds in ${ }^{3} \mathrm{~A}^{\prime}$ state of $\mathrm{FBr}{ }^{\prime \prime} \mathrm{OO}-\mathrm{OO}$ are slightly elongated by $0.01 \AA$, whereas $\mathrm{Br}{ }^{\prime \prime} \mathrm{O}$ distance is significantly shorter by $0.26 \AA$ (B3LYP), and the terminal O-O bond distance is very similar to that in free $\mathrm{O}_{2}\left({ }^{3} \Sigma_{\mathrm{g}}{ }^{-}\right)(1.194-1.245 \AA)$ [55].

It is worthy to note that the geometries predicted using the five functionals are all similar, with small variations in bond lengths and angles. The general trend for the covalent bond lengths is BLYP > BP86 > B3LYP $>$ B3P86 $>$ BHLYP. According to previous studies on geometries of $\mathrm{BrOF}_{\mathrm{n}} / \mathrm{BrOF}_{\mathrm{n}}{ }^{-}$, $\mathrm{FBrO}_{2} / \mathrm{FBrO}_{3}, \mathrm{BrClF}_{\mathrm{n}} / \mathrm{BrClF}_{\mathrm{n}}$ and $\mathrm{BrF}_{\mathrm{n}}$ species $[34,35,37,56]$, the hybrid DFT methods (BHLYP, 
B3P86 or B3LYP method) are excellent methods for the prediction of covalent bond lengths. The B3LYP method taking the median position may be regarded as a compromise between the reliabilities of geometry and thermochemical parameter predictions. This order coincides with that predicted for the FO molecule [25] where comparison with experiment indicates the B3LYP method to be the most accurate in prediction of geometry, and for $\mathrm{BrO}$ in predictions of bond dissociation and adiabatic electron affinity $\left(\mathrm{EA}_{\mathrm{ad}}\right)[21]$.

The attachment of an electron to $\mathrm{FBr}$...OO...OO complex, results in the ${ }^{4} \mathrm{~A}^{\prime}$ ground state for anion (aa: ${ }^{4} \mathrm{~A}^{\prime}$ in Figure 2). As might be expected, this structure is more stable than other anionic $\mathrm{BrO}_{4} \mathrm{~F}^{-} \mathrm{Br}$ hypervalent structures (ab: ${ }^{2} \mathrm{~A}^{\prime}$ and ac: ${ }^{2} \mathrm{~A}^{\prime}$ in Figure 2) by 32 and $78 \mathrm{kcal} / \mathrm{mol}$ at B3LYP/DZP++ level. The covalent bond lengths are predicted to be 1.975-2.059 $\AA$ for the Br-F bond, and 1.284-1.302 $\AA$ for interim O-O and 1.194-1.270 $\AA$ for the terminal O-O bond, and the complex bond distances are 2.053$2.264 \AA$ for $\mathrm{Br} . . \mathrm{O}$, and 2.806-3.183 $\AA$ for $(\mathrm{O}) \mathrm{O}{ }^{\cdots} \mathrm{O}(\mathrm{O})$ in the ${ }^{4} \mathrm{~A}^{\prime}$ state of $\mathrm{BrO}_{4} \mathrm{~F}^{-}$. Comparison with the similar neutral isomer shows that there is a substantial change in geometry between neutral ${ }^{3} \mathrm{~A}^{\prime}$ state and anionic ${ }^{4} \mathrm{~A}^{\prime}$ state. The Br-F bond (2.013 $\AA$ at B3LYP level), the interim O-O bond (1.295 $\AA$ ) and $\mathrm{Br} . . \mathrm{O}$ bond $(2.157 \AA)$ in anionic ${ }^{4} \mathrm{~A}^{\prime}$ state are analogous to those of $(\mathrm{FBr}-\mathrm{OO})^{-}(2.038 \AA$ for $\mathrm{Br}-\mathrm{F}$, $1.302 \AA$ for $\mathrm{O}-\mathrm{O}$, and $2.135 \AA$ for $\mathrm{Br} . . \mathrm{O})$ [35]; the terminal $\mathrm{O}-\mathrm{O}$ bond in the ${ }^{4} \mathrm{~A}^{\prime}$ state of $\mathrm{BrO}_{4} \mathrm{~F}^{-}$ $(1.230 \AA)$ is similar to that of free $\mathrm{O}_{2}(1.219 \AA$ at $\mathrm{B} 3 \mathrm{LYP}$ level) [55]; the $(\mathrm{O}) \mathrm{O} \cdots \mathrm{O}(\mathrm{O})$ distance of 2.806 $\AA$ in anionic $\mathrm{BrO}_{4} \mathrm{~F}^{-}$is substantially longer than the corresponding $(\mathrm{O}) \mathrm{O} \cdots \mathrm{O}(\mathrm{O})$ distance $(1.891 \AA)$ in ${ }^{3} \mathrm{~A}^{\prime}$ state of neutral $\mathrm{BrO}_{4} \mathrm{~F}$. Thus, this $\mathrm{BrO}_{4} \mathrm{~F}^{-}$structure in ${ }^{4} \mathrm{~A}^{\prime}$ state could be regarded as a van der Waals complex between $(\mathrm{FBr}-\mathrm{OO})^{-}[35]$ and $\mathrm{O}_{2}\left({ }^{3} \Sigma_{\mathrm{g}}{ }^{-}\right)$due to suitable $\mathrm{Br} \ldots \mathrm{O}$ and $(\mathrm{O}) \mathrm{O} \cdots \mathrm{O}(\mathrm{O})$ bonding distances, and the high negative charge of FBr-OO moiety (near to -1 from NBO analysis). Neither theoretical nor experimental values of $\mathrm{BrO}_{4} \mathrm{~F} / \mathrm{BrO}_{4} \mathrm{~F}^{-}$are available for comparison. For this structure in its doublet ${ }^{2} \mathrm{~A}^{\prime}$ state, the results of all five DFT methods are suspect due to the large spin contamination, with $<\mathrm{S}^{2}>=1.77$ or 1.76 .

For the cis- and trans- BrOO...OOF (c: ${ }^{1} \mathrm{~A}$ and d: ${ }^{1} \mathrm{~A}$ in Figure 1) structures, the bond lengths are calculated to be 1.846-2.123 $\AA$ for the $\mathrm{Br}-\mathrm{O}$ bond (that in cis-form tinily shorter than in trans-like), 1.402-1.642 $\AA$ for the F-O bond, 1.401-1.987 $\AA$ for the central single O-O bond, and 1.233-1.374 $\AA$ for outer $\mathrm{O}-\mathrm{O}$ bonds connected by $\mathrm{Br}$ and $\mathrm{F}$. In the cis- BrOO...OOF, the $\mathrm{O}$...OO fragment nearly in a planar, both $\mathrm{BrO}$ and $\mathrm{FO}$ bonds are almost perpendicular to this planar, however, in the transBrOO...OOF, the OO...OO chain nearly in a planar, the $\mathrm{BrO}$ and $\mathrm{FO}$ bonds are also almost perpendicular to this planar. At B3LYP level, both BrOO...OOF isomers nearly possess the same stability. This BrOO...OOF conformation could be viewed as a complex comprising of unstable BrOO and FOO molecules, furthermore, the DFT methods predict it thermodynamic instability with respect to dissociation into $\mathrm{BrOO}+\mathrm{FOO}$ (not shown).

For the $\mathrm{BrOO}_{2} \ldots \mathrm{OF}\left(\mathrm{e}:{ }^{1} \mathrm{~A}\right)$ structures, the bond lengths are calculated to be $1.768-1.792 \AA$ for the Br-O bond, 1.345-1.408 $\AA$ for the F-O bond, 1.200-1.230 $\AA$ for the central double $\mathrm{O}-\mathrm{O}$ bond and 1.573-1.946 $\AA, 1.7514-1.884 \AA$ for outer single $\mathrm{O}-\mathrm{O}$ bonds connected by $\mathrm{Br}$ and $\mathrm{F}$, respectively. At B3LYP level, the Br-O (1.781 $\AA$ ) or F-O (1.376 $\AA$ ) bond is slightly longer than that in BrO [21] or FO [25]. Thus, this $\mathrm{BrOO}_{2} \ldots$ OF (e: ${ }^{1} \mathrm{~A}$ ) structures could be regarded as a complex comprising of simple $\mathrm{BrO}, \mathrm{O}_{2}$ and FO molecules. The hybrid DFT methods predict it thermodynamic instability with respect to dissociation into $\mathrm{BrO}+\mathrm{O}_{2}+\mathrm{OF}$ (not shown), whereas the pure DFT methods predict the reaction 
energy of about 10 (BP86) and $6 \mathrm{kcal} / \mathrm{mol}(\mathrm{BLYP})$ for $\mathrm{BrOO}_{2} \ldots \mathrm{OF}\left(\mathbf{e}:{ }^{1} \mathrm{~A}\right) \rightarrow \mathrm{BrO}+\mathrm{O}_{2}+\mathrm{OF}$ (not shown).

Figure 2. Optimized geometries of anionic $\mathrm{BrO}_{4} \mathrm{~F}^{-}$(aa-ac) with $\mathrm{DFT} / \mathrm{DZP}++$ approach (bond lengths in $\AA$, bond angles and dihedral angles in degrees). A: represents bond angle, D: represents torsion angle.

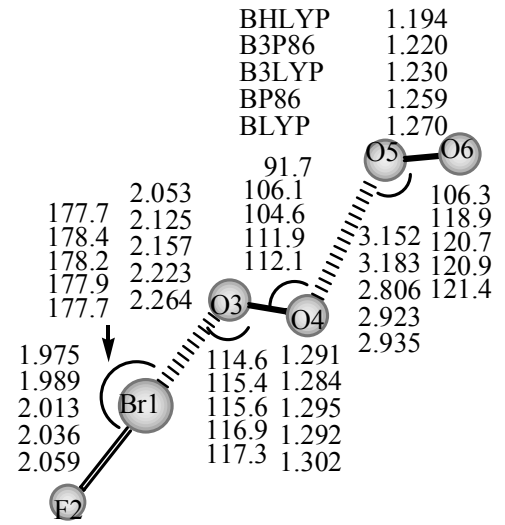

(aa) $(\mathrm{FBr} . . . \mathrm{OO} \ldots \mathrm{OOO})^{-} \mathrm{C}_{\mathrm{s}}\left({ }^{4} \mathrm{~A}^{\prime}\right)$

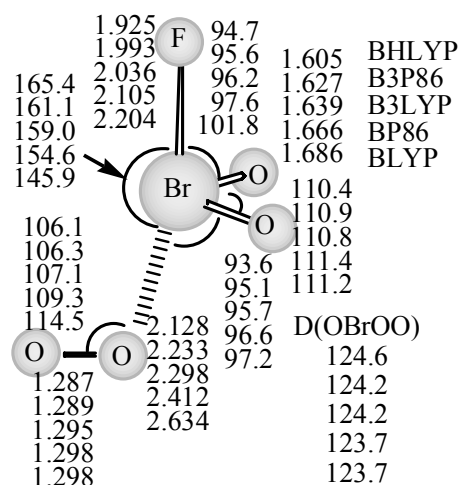

(ab) $\left(\mathrm{FBr}\left(\mathrm{O}_{2}\right) \ldots \mathrm{OO}\right)^{-} \mathrm{C}_{\mathrm{s}}\left({ }^{2} \mathrm{~A}^{\prime}\right)$

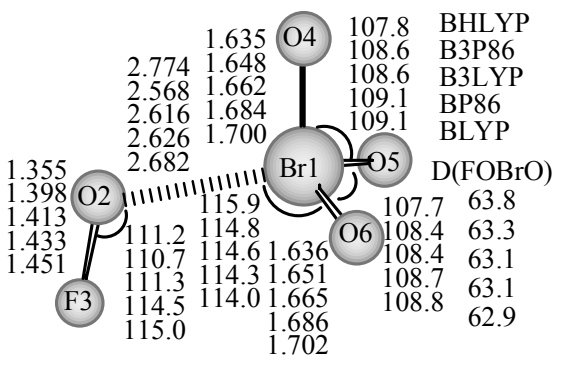

(ac) $\left.\left(\mathrm{FO} . . . \mathrm{BrO}_{3}\right)^{-} \mathrm{C}_{\mathrm{s}}{ }^{2} \mathrm{~A}^{\prime}\right)$

For Br-hypervalent structures: $\mathrm{O}_{2} \mathrm{Br}$...OOF (f: ${ }^{1} \mathrm{~A}$ ), the bond lengths are predicted to be 1.592 $1.682 \AA$ for $\mathrm{Br}^{-} \mathrm{O}_{\text {term }}$ (with an oxygen atom at the terminal position), 1.981-2.501 $\AA$ for $\mathrm{Br}-\mathrm{O}_{\text {mid }}$ (with $\mathrm{O}$ atom at the middle position), and 1.246-1.319 $\AA$ for $\mathrm{O}-\mathrm{O}$, and $1.408-1.638 \AA$ for F-O. The predicted Br-O $\mathrm{O}_{\text {term }}$ length is comparable to that of $\mathrm{OBrO}$ (1.649 $\AA$ ) [21], F-O or O-O bond distances are slightly shorter or longer than those in FOO (1.649 or $1.200 \AA)$ [18]. This structure could be thought as a complex between $\mathrm{BrO}_{2}$ and FOO. Likewise, the hybrid DFT methods predict it thermodynamic instability with respect to dissociation into $\mathrm{BrO}_{2}+\mathrm{FOO}$ (not shown), and the pure DFT methods predict the dissociation energy of $\mathrm{O}_{2} \mathrm{Br}$...OOF (f: $\left.{ }^{1} \mathrm{~A}\right) \rightarrow \mathrm{BrO}_{2}+$ FOO reaction is about 2.3 (BP86) and $0.5 \mathrm{kcal} / \mathrm{mol}$ (BLYP) respectively (not shown).

For the rare $\mathrm{Br}(\mathrm{VII}) \mathrm{FBrO}_{3} \ldots \mathrm{O}\left(\mathrm{g}: \mathrm{C}_{3 \mathrm{v}},{ }^{3} \mathrm{~A}_{1}\right.$ ) complex between $\mathrm{FBrO}_{3}$ and $\mathrm{O}$ atom, the bond lengths are predicted to be 1.573-1.639 $\AA$ for $\mathrm{Br}-\mathrm{O}, 1.738-1.832 \AA$ for $\mathrm{Br}-\mathrm{F}$, and 3.039-3.168 $\AA$ for $\mathrm{Br}$...O. At B3LYP level, $\mathrm{Br}-\mathrm{O}$ bond long is $1.604 \AA$, analogous to that in $\mathrm{BrO}_{4}^{-}(1.603 \AA)$ [21] or $\mathrm{BrO}_{3} \mathrm{~F}_{2}^{-}(1.601$ $\AA$ ) [31], and longer than that in $\mathrm{FBrO}_{3}\left(1.582 \AA\right.$ ) [35], however, significantly shorter than that in $\mathrm{BrO}_{3}{ }^{-}$ $(1.648 \AA)$ [21]. The Br-F bond length is $1.804 \AA$, being significantly shorter than that in $\mathrm{BrO}_{3} \mathrm{~F}_{2}^{-}$ (1.872 or $1.849 \AA$ ) [31], while substantially longer than that in $\mathrm{FBrO}_{3}(1.708 \AA$ ) [35]. $\angle \mathrm{FBrO}$ and $\angle \mathrm{OBrO}$ angles are 101.4 and $116.2^{\circ}$ respectively, slightly narrower than those in $\mathrm{FBrO}_{3}$ theoretically (101.9 and 115.9) or experimentally (103.3 and $114.9^{\circ}$ ) [27]. Generally, the predicted lengths are comparable to those of $\mathrm{FBrO}_{3}\left(\mathrm{C}_{3 \mathrm{v}}\right)$ and $\mathrm{BrO}_{3} \mathrm{~F}_{2}{ }^{-}$anion [31]. The DFT methods predict the dissociation energy of $\mathrm{FBrO}_{3} \ldots \mathrm{O}\left(\mathrm{g}: \mathrm{C}_{3 \mathrm{v}},{ }^{3} \mathrm{~A}_{1}\right) \rightarrow \mathrm{FBrO}_{3}\left(\mathrm{C}_{3 \mathrm{v}}\right)+\mathrm{O}$ reaction is about $1 \mathrm{kcal} / \mathrm{mol}$ (Table 1$)$, demonstrating that this $\mathrm{Br}(\mathrm{VII}) \mathrm{FBrO}_{3} \ldots \mathrm{O}\left(\mathrm{g}: \mathrm{C}_{3 \mathrm{v}},{ }^{3} \mathrm{~A}_{1}\right)$ hypervalent structure is bound for dissociation to $\mathrm{FBrO}_{3}$ and $\mathrm{O}$.

The corresponding anion eventually to dissociation into $\mathrm{FBr}\left(\mathrm{O}_{2}\right)^{-} \ldots \mathrm{OO}\left(\mathbf{a b}:{ }^{2} \mathrm{~A}^{\prime}\right)$ complex structure, $\mathrm{Br}-\mathrm{F}$ and $\mathrm{Br}-\mathrm{O}$ bonds are elongated to be 2.036 and $1.639 \AA$ (B3LYP), the Br...O complex distance and O-O bond length are about 2.3 and $1.30 \AA$. The DFT methods predict the dissociation energy of 
$\mathrm{FBr}\left(\mathrm{O}_{2}\right)^{-} \ldots \mathrm{OO}\left(\mathbf{a b}:{ }^{2} \mathrm{~A}^{\prime}\right) \rightarrow \mathrm{BrF}^{-}+\mathrm{O}_{2}\left({ }^{3} \Sigma_{\mathrm{g}}{ }^{-}\right)+\mathrm{O}_{2}\left({ }^{1} \Delta_{\mathrm{g}}\right)$ reaction being in the range of $7-48 \mathrm{kcal} / \mathrm{mol}$, the BHLYP result is too small $(7 \mathrm{kcal} / \mathrm{mol})$. This is not unexpected, given the large fraction of exact exchange in the BHLYP method [57]. For the global minimum FBr...OO...OO anion (aa: $\left.{ }^{4} \mathrm{~A}^{\prime}\right)$, the predictions of five different DFT methods for the dissociation energies for aa to dissociate to its components $\left[\mathrm{FBr}^{\cdots} \mathrm{OO}^{-}\left({ }^{2} \mathrm{~A}^{\prime \prime}\right)+\mathrm{O}_{2}, \mathrm{FBr}^{\cdots} \mathrm{OO}\left({ }^{3} \mathrm{~A}^{\prime \prime}\right)+\mathrm{O}_{2}^{-}\right.$, or $\left.\mathrm{BrF}^{-}+2 \mathrm{O}_{2}\left({ }^{3} \Sigma_{\mathrm{g}}{ }^{-}\right)\right]$show the same trend, i.e. the pure DFT (BP86 and BLYP) methods predict higher dissociation energies than the hybrid DFT methods, and the BHLYP result is the smallest.

For the higher-lying hypervalent anionic $\left(\mathrm{FO} \ldots \mathrm{BrO}_{3}\right)^{-}$complex structure (ac: $\left.{ }^{2} \mathrm{~A}^{\prime}\right)$, the bond lengths are predicted to be 1.635-1.702 $\AA$ for Br-O bonds, 1.355-1.451 $\mathrm{A}$ for F-O bond, 1.355-1.451 for F-O bond, and 2.568-2.774 $\AA$ for Br...O complex bond. The theoretical dissociation energies for $\left(\mathrm{FO} . . \mathrm{BrO}_{3}\right)^{-} \rightarrow \mathrm{BrO}_{3}{ }^{-}\left(\mathrm{C}_{3 \mathrm{v}}\right)+\mathrm{FO}$ is in the range of 2.8-17.9 $\mathrm{kcal} / \mathrm{mol}$ (Table 2). Likewise, the pure DFT methods predict higher dissociation energies, and the BHLYP result is the lowest.

Table 2. Relative energies (corrected with $\mathrm{ZPVE}$ ) in $\mathrm{kcal} \mathrm{mol}^{-1}$ for the $\mathrm{BrO}_{4} \mathrm{~F}^{-}$species ${ }^{\mathrm{a}}$.

\begin{tabular}{|c|c|c|c|c|c|}
\hline & BHLYP & B3P86 & B3LYP & BP86 & BLYP \\
\hline aa $\left(C_{s},{ }^{4} A^{\prime}\right)$ & 0.00 & 0.00 & 0.00 & 0.00 & 0.00 \\
\hline $\mathbf{a b}\left(C_{s},{ }^{2} A^{\prime}\right)$ & 44.67 & 27.77 & 32.06 & 22.02 & 25.84 \\
\hline $\operatorname{ac}\left(C_{s},{ }^{2} A^{\prime}\right)$ & 89.41 & 74.36 & 78.47 & 69.67 & 73.64 \\
\hline FBr' $^{\prime \prime O O O}\left({ }^{2} \mathbf{A}^{\prime \prime}\right)+\mathbf{O}^{b}$ & 62.73 & 72.17 & 71.24 & 78.52 & 77.23 \\
\hline $\mathrm{FBr}^{\cdots} \mathrm{OO}^{-}\left({ }^{2} \mathbf{A}^{\prime \prime}\right)+\mathbf{O}_{2}{ }^{b}$ & 1.02 & 1.49 & 1.38 & 4.42 & 4.90 \\
\hline $\mathrm{OBrF}^{-}+\mathbf{O}_{3}^{b}$ & 72.04 & 59.70 & 60.46 & 52.44 & 54.10 \\
\hline $\operatorname{FBr}{ }^{\cdots} O^{\prime} O O\left({ }^{1} A^{\prime}\right)+O^{-b}$ & 143.20 & 137.42 & 135.97 & 127.36 & 126.87 \\
\hline $\mathrm{FBr} \mathbf{C O O}^{3}\left(^{\prime \prime}\right)+\mathrm{O}_{2}^{-\mathrm{b}}$ & 50.96 & 60.66 & 57.87 & 69.20 & 67.16 \\
\hline $\operatorname{OBrF}\left({ }^{1} \mathbf{A}^{\prime}\right)+\mathbf{O}_{3}^{-b}$ & 92.18 & 79.32 & 80.61 & 75.51 & 76.23 \\
\hline $\mathrm{BrF}^{-}+2 \mathrm{O}_{2}\left({ }^{3} \Sigma_{\mathrm{g}}\right)^{\mathrm{b}}$ & -1.39 & 11.42 & 9.06 & 20.79 & 19.59 \\
\hline $\mathrm{BrO}_{3}^{-}+\mathrm{OF}^{\mathrm{b}}$ & 92.59 & 86.40 & 90.39 & 87.94 & 92.27 \\
\hline
\end{tabular}

Generally, the theoretical dissociation energies $\left(\mathrm{D}_{\mathrm{e}}\right)$ for $\mathrm{BrO}_{4} \mathrm{~F} / \mathrm{BrO}_{4} \mathrm{~F}^{-}$species can be evaluated from the data in Tables 1 and 2. For the anionic $\mathrm{BrO}_{4} \mathrm{~F}^{-}$species, all of five DFT methods predict almost consistent relative energies and bond dissociation energies, with the exception of the lowest BHLYP results (Table 2) (vide supra). In contrast, for the neutral $\mathrm{BrO}_{4} \mathrm{~F}$ species (Table 1), the relative energies and bond dissociation energies predicted by BHLYP method are nearly the biggest. It is noted that BHLYP method perform poorly for bond-breaking process [57] due to the large (50\%) contribution from Hartree-Fock or exact exchange. Based on the previous studies of the $\mathrm{BrO}_{\mathrm{n}}$ species [21] and the anionic $\mathrm{BrO}_{4} \mathrm{~F}^{-}$species (vide supra), the B3LYP methods should predict reasonable dissociation energies and relative energies, however, caution is urged because of the complex of $\mathrm{BrO}_{4} \mathrm{~F}$ ternary system.

At B3LYP level, for the lowest energies species, the theoretical bond dissociation energies for neutral $\mathrm{BrO}_{4} \mathrm{~F}$ refer to the reactions: $\mathrm{BrO}_{4} \mathrm{~F} \rightarrow \mathrm{BrO}_{4-\mathrm{m}} \mathrm{F}+\mathrm{O}_{\mathrm{m}}(\mathrm{m}=1-4)$. For $\mathrm{BrO}_{4} \mathrm{~F} \rightarrow \mathrm{BrO}_{2} \mathrm{~F}\left({ }^{3} \mathrm{~A}^{\prime \prime}\right)$ [35] $+\mathrm{O}_{2}$, the theoretical reaction energies (ca. zero) are much smaller than those of $\mathrm{BrO}_{4} \mathrm{~F} \rightarrow \mathrm{BrO}_{3} \mathrm{~F}$ $\left({ }^{1} \mathrm{~A}^{\prime}\right)+\mathrm{O}$ (range from 84 to $109 \mathrm{kcal} / \mathrm{mol}$, about $100 \mathrm{kcal} / \mathrm{mol}$ at $\mathrm{B} 3 \mathrm{LYP}$ level) and $\mathrm{BrO}_{4} \mathrm{~F} \rightarrow \mathrm{BrOF}$ 
$\left({ }^{1} \mathrm{~A}^{\prime}\right)+\mathrm{O}_{3}$ (range from 48 to $101 \mathrm{kcal} / \mathrm{mol}$, ca. $71 \mathrm{kcal} / \mathrm{mol}$ at $\mathrm{B} 3 \mathrm{LYP}$ level), indicating the dissociation reaction is favored, which is consistent with the $\mathrm{FBr} \ldots \mathrm{O}_{2} \ldots \mathrm{O}_{2}$ complex structure.

The most reliable B3LYP method predicts the dissociation energy $\left(\mathrm{D}_{\mathrm{e}}\right)$ for F-Br... $\mathrm{O}_{2} \ldots \mathrm{O}_{2}\left({ }^{5} \mathrm{~A}^{\prime}\right) \rightarrow$ $\mathrm{BrF}+2 \mathrm{O}_{2}$ and $\left(\mathrm{F}-\mathrm{Br} . . \mathrm{O}_{2} \ldots \mathrm{O}_{2}\right)^{-}\left({ }^{4} \mathrm{~A}^{\prime}\right) \rightarrow \mathrm{BrF}^{-}+2 \mathrm{O}_{2}$ are only 0.0 and $9.1 \mathrm{kcal} / \mathrm{mol}$, respectively (Tables 1 and 2), suggesting a weak van der Waals interaction between the $\mathrm{BrF}$ or $\mathrm{BrF}^{-}$and $\mathrm{O}_{2}$ moieties.

For the anionic $\mathrm{BrO}_{4} \mathrm{~F}^{-}$species, the $\mathrm{D}_{\mathrm{e}}$ of $\mathrm{BrO}_{4} \mathrm{~F}^{-} \rightarrow \mathrm{BrO}_{4-\mathrm{m}} \mathrm{F}^{-}+\mathrm{O}_{\mathrm{m}}$ and $\mathrm{BrO}_{4} \mathrm{~F}^{-} \rightarrow \mathrm{BrO}_{4-\mathrm{m}} \mathrm{F}+\mathrm{O}_{\mathrm{m}}{ }^{-}$are predicted (Table 2). The bond dissociation energies for $\mathrm{BrO}_{4} \mathrm{~F}^{-} \rightarrow \mathrm{BrO}_{2} \mathrm{~F}^{-}+\mathrm{O}_{2}$ are smaller positive values, from 1.0 to $1.5 \mathrm{kcal} / \mathrm{mol}$ for three hybrid DFT methods and 4.4 or $4.9 \mathrm{kcal} / \mathrm{mol}$ for BP86 or BLYP (two pure DFT) methods. The $\mathrm{D}_{\mathrm{e}}$ values predicted by BHLYP method are too low to be reliable. The $\mathrm{D}_{\mathrm{e}}$ value of $1.4 \mathrm{kcal} / \mathrm{mol}$ predicted by $\mathrm{B} 3 \mathrm{LYP}$ is much smaller than those of $\mathrm{BrO}_{4} \mathrm{~F}^{-} \rightarrow$ $\mathrm{BrO}_{3} \mathrm{~F}^{-}+\mathrm{O}(71 \mathrm{kcal} / \mathrm{mol})$ and $\mathrm{BrO}_{4} \mathrm{~F}^{-} \rightarrow \mathrm{OBrF}^{-}+\mathrm{O}_{3}(60 \mathrm{kcal} / \mathrm{mol})$.

For $\mathrm{BrO}_{4} \mathrm{~F}^{-} \rightarrow \mathrm{BrO}_{4-\mathrm{m}} \mathrm{F}+\mathrm{O}_{\mathrm{m}}{ }^{-}$reactions, the higher bond dissociation energies are predicted, the $\mathrm{D}_{\mathrm{e}}$ value $(58 \mathrm{kcal} / \mathrm{mol})$ of $\mathrm{BrO}_{4} \mathrm{~F}^{-} \rightarrow \mathrm{BrO}_{2} \mathrm{~F}+\mathrm{O}_{2}^{-}$is also smaller than those of $\mathrm{BrO}_{4} \mathrm{~F}^{-} \rightarrow \mathrm{BrO}_{3} \mathrm{~F}+\mathrm{O}^{-}(136$ $\mathrm{kcal} / \mathrm{mol})$ and $\mathrm{BrO}_{4} \mathrm{~F}^{-} \rightarrow \mathrm{OBrF}+\mathrm{O}_{3}^{-}(81 \mathrm{kcal} / \mathrm{mol})$, and demonstrating that complex $\mathrm{BrO}_{\mathrm{n}} \mathrm{F}[34,35]$ species have higher electron affinities than the free $\mathrm{O}_{\mathrm{m}}$ species [55]. For the challenging $\mathrm{BrO}_{\mathrm{m}} \mathrm{F} / \mathrm{BrO}_{\mathrm{m}} \mathrm{F}^{-}(\mathrm{m}=1-4)$ species, minima on PES were found with all of DFT methods employed. However, the thermodynamic stabilities decrease with $\mathrm{n}$ (vide supra).

The $\mathrm{EA}_{\mathrm{ad}}$ for $\mathrm{FBr}_{-} \mathrm{O}_{2}-\mathrm{O}_{2}\left(\mathrm{a}:{ }^{3} \mathrm{~A}^{\prime} \leftarrow\right.$ aa: $\left.{ }^{4} \mathrm{~A}^{\prime}\right)$ are predicted to be $4.95 \mathrm{eV}(\mathrm{BHLYP}), 4.97 \mathrm{eV}(\mathrm{B} 3 \mathrm{P} 86)$, and $4.52 \mathrm{eV}(\mathrm{B} 3 \mathrm{LYP})$, zero-point corrected $\mathrm{EA}_{\mathrm{ad}}\left(\mathrm{EA}_{\text {zero }}\right)$ is only increased about $0.05 \mathrm{eV}$. At B3LYP level, $\mathrm{EA}_{\text {zero }}$ is $4.57 \mathrm{eV}$, larger than those of FBr-OOO [35] and $\mathrm{FBrO}$ [34] by about 0.1 and $1.9 \mathrm{eV}$ respectively, and much smaller than those of FBr-OO by $1.3 \mathrm{eV}$ (B3LYP). Those with odd $\mathrm{n}(\mathrm{n}=1$ and 3, closed shell) have smaller EAs than those of species for the even number of $n(n=2$ and 4), which are open-shell triplet state. The $\mathrm{EA}_{\mathrm{vert}}$ values range from 2.13 to $3.55 \mathrm{eV}$. The range of VDE is from 4.49 to $4.98 \mathrm{eV}$. No experimental data are available.

The harmonic vibrational frequencies and IR active intensities of $\mathrm{BrO}_{4} \mathrm{~F} / \mathrm{BrO}_{4} \mathrm{~F}^{-}$species predicted by B3LYP method are available in Tables 3 and 4 . For triplet state $\mathrm{FBr} . . . \mathrm{O}_{2} \ldots \mathrm{O}_{2}(\mathbf{a})\left(C_{s},{ }^{3} \mathrm{~A}^{\prime}\right)$, the calculated infrared spectrum is characterized by three strong bands around 1561 (terminal O-O symmetri stretch(s.s.)), 1440 (middle O-O s.s.), $628 \mathrm{~cm}^{-1}$ (F-Br s.s.), all other modes give rise to weak intensities. For singlet state FBr...OOOO (b) $\left(\mathrm{C}_{1},{ }^{1} \mathrm{~A}\right)$, the bands of ca. 1508 (terminal O-O s.s.), 1391 (middle O-O s.s.), and $620 \mathrm{~cm}^{-1}$ (F-Br s.s.) possess the stronger intensities. For BrOO...OOF chain structures (c) and (d), the predicted infrared spectrum are characterized by three stronger bands around 1223, 1376 (F-connected O-O s.s.), 1107, 1276 (Br-connected O-O s.s.), and 720, $667 \mathrm{~cm}^{-1}$ (F$\mathrm{O}-\mathrm{O}$ bend), respectively, the rest modes yield weak intensities. For BrOO2...OF structure (e), four bands around $1209,934,862$, and $718 \mathrm{~cm}^{-1}$ exist the stronger intensities, the corresponding modes are $\mathrm{O}-\mathrm{O}(\mathrm{O} 2)$ s.s., F-O s.s., Br-O s.s., and O...O stretch.

For $\mathrm{O}_{2} \mathrm{Br}$...OOF structure (f), four bands around $1529,1055,732$, and $618 \mathrm{~cm}^{-1}$ possess the stronger intensities, the corresponding modes are $\mathrm{O}-\mathrm{O}$ stretch, $\mathrm{OBrO}$ asymmetric bend, OBrO symmetric bend, and $\mathrm{FOO}$ bend. For the highest symmetric $\mathrm{Br}(\mathrm{VII}) \mathrm{FBrO}_{3} . . \mathrm{O}(\mathrm{g})$, theoretical infrared spectrum are characterized by the stronger bands around $\theta: 955 \mathrm{~cm}^{-1}\left(\mathrm{BrO}_{3}\right.$ asymmetric stretch (a.s.)); $\eta: 864 \mathrm{~cm}^{-1}$ ( $\mathrm{BrO}_{3}$ symm.bend); $\zeta: 567 \mathrm{~cm}^{-1}$ (F-Br s.s.); $\varepsilon: 364 \mathrm{~cm}^{-1}$ (OBrO in the planar bend); $\delta: 345 \mathrm{~cm}^{-1}$ (OBrO out of planar bend), the harmonic vibrational frequencies of $\mathrm{BrO}_{3}$ radical are larger than the 
corresponding $\mathrm{BrO}_{3}^{+}[32]\left(966,850,329\right.$, and $\left.231 \mathrm{~cm}^{-1}\right)$. For anionic quartet state $\mathrm{FBr} . . \mathrm{OO}$...OO (aa) $\left(\mathrm{C}_{\mathrm{s}},{ }^{4} \mathrm{~A}^{\prime}\right)$ species, four bands around $1532,1226,383$, and $227 \mathrm{~cm}^{-1}$ possess the stronger intensities. For anionic hypervalency structure $\left[\mathrm{FO} \ldots \mathrm{Br}(\mathrm{O}) \mathrm{O}_{2}\right]^{-}(\mathbf{a c})\left(\mathrm{C}_{\mathrm{s}},{ }^{2} \mathrm{~A}^{\prime}\right)$, four bands around 957, 812, 805, $789 \mathrm{~cm}^{-1}$ possess the stronger intensities.

Table 3. Predicted total energies $\left(E_{\text {total }}\right)$ in hartree, zero-point vibrational energies (ZPE) in $\mathrm{kcal} \mathrm{mol}{ }^{-1}$, and harmonic vibrational frequencies (Freq) in $\mathrm{cm}^{-1}$ and the infrared intensities (in parenthese, in $\mathrm{km} \cdot \mathrm{mol}^{-1}$ ) for the minimum-energy $\mathrm{BrO}_{4} \mathrm{~F}(\mathbf{a}, \mathbf{b}, \mathbf{c}, \mathbf{d}$, and e) structures at the B3LYP/DZP++ level.

\begin{tabular}{llllll}
\hline Isomers & $\mathbf{a}\left(\mathbf{C}_{\mathbf{s}},{ }^{\mathbf{3}} \mathbf{A}^{\prime}\right)$ & $\mathbf{b}\left(\mathbf{C}_{\mathbf{1}},{ }^{\mathbf{1}} \mathbf{A}\right)$ & $\mathbf{c}\left(\mathbf{C}_{\mathbf{1}},{ }^{\mathbf{1}} \mathbf{A}\right)$ & $\mathbf{d}\left(\mathbf{C}_{\mathbf{1}},{ }^{\mathbf{1}} \mathbf{A}\right)$ & $\mathbf{e}\left(\mathbf{C}_{\mathbf{1}},{ }^{\mathbf{1}} \mathbf{A}\right)$ \\
\hline $\mathbf{E}_{\text {total }}$ & -2974.61676 & -2974.57337 & -2974.56896 & -2974.56840 & -2974.54599 \\
$\mathbf{Z P E}$ & \multicolumn{1}{c}{7.37} & 7.88 & 8.53 & 8.22 & 8.05 \\
Freq & $\omega_{1}\left(\mathrm{a}^{\prime \prime}\right) 27(<1)$ & $\omega_{1} 13(<1)$ & $\omega_{1} 28(<1)$ & $\omega_{1} 24(<1)$ & $\omega_{1} 79(<1)$ \\
& $\omega_{2}\left(\mathrm{a}^{\prime}\right) 35(1)$ & $\omega_{2} 61(1)$ & $\omega_{2} 97(1)$ & $\omega_{2} 59(1)$ & $\omega_{2} 98(<1)$ \\
& $\omega_{3}\left(\mathrm{a}^{\prime \prime}\right) 67(<1)$ & $\omega_{3} 81(3)$ & $\omega_{3} 175(3)$ & $\omega_{3} 103(<1)$ & $\omega_{3} 133(0)$ \\
& $\omega_{4}\left(\mathrm{a}^{\prime}\right) 68(5)$ & $\omega_{4} 97(7)$ & $\omega_{4} 249(7)$ & $\omega_{4} 201(0)$ & $\omega_{4} 211(14)$ \\
& $\omega_{5}\left(\mathrm{a}^{\prime \prime}\right) 96(1)$ & $\omega_{5} 110(2)$ & $\omega_{5} 287(3)$ & $\omega_{5} 252(4)$ & $\omega_{5} 247(2)$ \\
& $\omega_{6}\left(\mathrm{a}^{\prime}\right) 102(2)$ & $\omega_{6} 225(1)$ & $\omega_{6} 367(13)$ & $\omega_{6} 281(36)$ & $\omega_{6} 338(16)$ \\
& $\omega_{7}\left(\mathrm{a}^{\prime}\right) 206(4)$ & $\omega_{7} 292(5)$ & $\omega_{7} 501(44)$ & $\omega_{7} 444(28)$ & $\omega_{7} 451(3)$ \\
& $\omega_{8}\left(\mathrm{a}^{\prime}\right) 276(10)$ & $\omega_{8} 345(3)$ & $\omega_{8} 546(33)$ & $\omega_{8} 496(63)$ & $\omega_{8} 502(32)$ \\
& $\omega_{9}\left(\mathrm{a}^{\prime}\right) 628(132)$ & $\omega_{9} 620(142)$ & $\omega_{9} 664(60)$ & $\omega_{9} 571(1)$ & $\omega_{9} 718(148)$ \\
& $\omega_{10}\left(\mathrm{a}^{\prime}\right) 650(<1)$ & $\omega_{10} 766(<1)$ & $\omega_{10} 720(74)$ & $\omega_{10} 667(172)$ & $\omega_{10} 862(86)$ \\
& $\omega_{11}\left(\mathrm{a}^{\prime}\right) 1440(643)$ & $\omega_{11} 1393(529)$ & $\omega_{11} 1107(105)$ & $\left.\omega_{11} 1276162\right)$ & $\omega_{11} 934(93)$ \\
& $\omega_{12}\left(\mathrm{a}^{\prime}\right) 1561(110)$ & $\omega_{12} 1508(278)$ & $\omega_{12} 1223(112)$ & $\omega_{12} 1376(69)$ & $\omega_{12} 1209(161)$ \\
\hline
\end{tabular}

Table 4. Predicted total energies $\left(E_{\text {total }}\right)$ in hartree, zero-point vibrational energies (ZPE) in $\mathrm{kcal} \mathrm{mol}{ }^{-1}$, and harmonic vibrational frequencies (Freq) in $\mathrm{cm}^{-1}$ and the infrared intensities (in parenthese, in $\mathrm{km} \mathrm{mol}^{-1}$ ) for the minimum-energy $\mathrm{BrO}_{4} \mathrm{~F} / \mathrm{BrO}_{4} \mathrm{~F}^{-}$(f, g/aa, ac) structures at the B3LYP/DZP++ level.

\begin{tabular}{lllll}
\hline Isomers & $\mathbf{f}\left(\mathbf{C}_{\mathbf{1}},{ }^{\mathbf{1}} \mathbf{A}\right)$ & $\mathbf{g}\left(\mathbf{C}_{\mathbf{3 v}},{ }^{\mathbf{3}} \mathbf{A}_{\mathbf{1}}\right)$ & $\mathbf{a a}\left(\mathbf{C}_{\mathbf{s}},{ }^{\mathbf{4}} \mathbf{A}^{\prime}\right)$ & $\mathbf{a c}\left(\mathbf{C}_{\mathbf{s}}{ }^{\mathbf{2}} \mathbf{A}^{\prime}\right)$ \\
\hline $\mathbf{E}_{\text {total }}$ & -2974.52034 & -2974.46217 & -2974.78297 & -2974.65675 \\
ZPE & 8.47 & 7.28 & 6.22 & 7.03 \\
Freq & $\omega_{1} 41(<1)$ & $\omega_{1}(\mathrm{e}) \alpha 39(<1)$ & $\omega_{1}\left(\mathrm{a}^{\prime}\right) 13(<1)$ & $\omega_{1}\left(\mathrm{a}^{\prime \prime}\right) 31(1)$ \\
& $\omega_{2} 104(0)$ & $\omega_{2}\left(\mathrm{a}_{1}\right) \beta 66(<1)$ & $\omega_{2}\left(\mathrm{a}^{\prime \prime}\right) 16(<1)$ & $\omega_{2}\left(\mathrm{a}^{\prime}\right) 56(3)$ \\
& $\omega_{3} 110(1)$ & $\omega_{3}(\mathrm{e}) \gamma 269(<1)$ & $\omega_{3}\left(\mathrm{a}^{\prime \prime}\right) 34(<1)$ & $\omega_{3}\left(\mathrm{a}^{\prime \prime}\right) 77(4)$ \\
& $\omega_{4} 231(4)$ & $\omega_{4}\left(\mathrm{a}_{1}\right) \delta 345(25)$ & $\omega_{4}\left(\mathrm{a}^{\prime}\right) 49(3)$ & $\omega_{4}\left(\mathrm{a}^{\prime}\right) 90(2)$ \\
& $\omega_{5} 246(5)$ & $\omega_{5}(\mathrm{e}) \varepsilon 364(30)$ & $\omega_{5}\left(\mathrm{a}^{\prime}\right) 102(5)$ & $\omega_{5}\left(\mathrm{a}^{\prime}\right) 200(8)$ \\
& $\omega_{6} 283(4)$ & $\omega_{6}\left(\mathrm{a}_{1}\right) \zeta 567(144)$ & $\omega_{6}\left(\mathrm{a}^{\prime}\right) 151(29)$ & $\omega_{6}\left(\mathrm{a}^{\prime \prime}\right) 327(14)$ \\
& $\omega_{7} 438(30)$ & $\omega_{7}\left(\mathrm{a}_{1}\right) \eta 864(21)$ & $\omega_{7}\left(\mathrm{a}^{\prime \prime}\right) 181(7)$ & $\omega_{7}\left(\mathrm{a}^{\prime}\right) 327(14)$ \\
& $\omega_{8} 535(5)$ & $\omega_{8}(\mathrm{e}) \theta 955(106)$ & $\omega_{8}\left(\mathrm{a}^{\prime}\right) 227(45)$ & $\omega_{8}\left(\mathrm{a}^{\prime}\right) 390(63)$ \\
& $\omega_{9} 618(6)$ & & $\omega_{9}\left(\mathrm{a}^{\prime}\right) 383(636)$ & $\omega_{9}\left(\mathrm{a}^{\prime}\right) 789(100)$ \\
& $\omega_{10} 732(42)$ & & $\omega_{10}\left(\mathrm{a}^{\prime}\right) 437(25)$ & $\omega_{10}\left(\mathrm{a}^{\prime}\right) 805(174)$ \\
& $\omega_{11} 1055(131)$ & & $\omega_{11}\left(\mathrm{a}^{\prime}\right) 1226(116)$ & $\omega_{11}\left(\mathrm{a}^{\prime}\right) 812(181)$ \\
& $\omega_{12} 1529(360)$ & & $\omega_{12}\left(\mathrm{a}^{\prime}\right) 1532(1291)$ & $\omega_{12}\left(\mathrm{a}^{\prime}\right) 957(397)$ \\
\hline
\end{tabular}


Isodesmic reactions, which have been typically used to obtain the heats of formation for many molecules, are those in which the reactants and products contain the same types of bonds, i.e., the number of bonds broken and formed is conserved [58]. An isodesmic reaction scheme requires that the heats of formation of all the molecules involved in the reaction to be known with the exception of the heat of formation of the particular isomer. Because of this property, errors in the energy that might occur due to defects in the basis set and electron correlation cancel, to a large extent. The isodesmic scheme used here is $\mathrm{BrOOOOF}+4 \mathrm{HOH} \rightarrow 3 \mathrm{HOOH}+\mathrm{HOBr}+\mathrm{HOF}$. During the calculation of the heat of formation of BrOOOOF using the isodesmic scheme, literature values for the heats of formation of $\mathrm{HOH}\left(-57.10 \mathrm{kcal} \mathrm{mol}{ }^{-1}\right)$ [59], $\mathrm{HOOH}\left(-31.02 \mathrm{kcal} \mathrm{mol}^{-1}\right)$ [59], and $\mathrm{HOBr}$ $\left(-10.93 \mathrm{kcal} \mathrm{mol}^{-1}\right)$ [60], HOF $\left(-22.47 \mathrm{kcal} \mathrm{mol}^{-1}\right)$ [61], were used. Using these results we were able to calculate the heats of reaction. For cis $\operatorname{BrOOOOF}(\mathbf{c})$, the heat of formation is predicted to be 50 $\mathrm{kcalmol}^{-1}$ at B3LYP level of theory (Table 5). Using the relative energies (Table 1) along with the heat

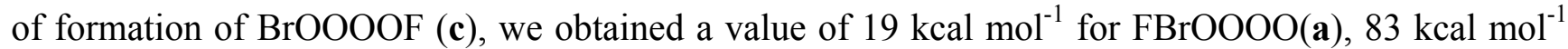
for $\mathrm{BrOO} 2 \ldots \mathrm{OF}(\mathbf{e}), 64 \mathrm{kcal} \mathrm{mol}^{-1}$ for $\mathrm{O}_{2} \mathrm{Br}$...OOF (f), and $116 \mathrm{kcal} \mathrm{mol}^{-1}$ for $\mathrm{FBrO}_{3} \ldots \mathrm{O}$ (g) (shown in Table 6). To further assess these results, we have listed all five DFT methods heats of formation of the isomers in Table 6. At present, there are no experimental measurements to which be mainly due to the incompleteness of the basis sets and only partial allowance for electron correlation.

Table 5. Isodesmic heats of reaction $\left(\mathrm{kcal} \mathrm{mol}^{-1}\right)$ and heats of formation of BrOOOOF (c).

\begin{tabular}{|c|c|c|c|c|c|c|c|}
\hline \multirow[b]{2}{*}{ Levels } & \multicolumn{5}{|c|}{ Total energies (hartrees) } & \multirow{2}{*}{$\begin{array}{c}\Delta H_{r, 0}^{0} \\
\mathrm{BrOOOOF}+4 \mathrm{H}_{2} \mathrm{O} \rightarrow \\
3 \mathrm{H}_{2} \mathrm{O}_{2}+\mathrm{HOBr}+\mathrm{HOF}\end{array}$} & \multirow{2}{*}{$\begin{array}{c}\Delta H_{\mathrm{f}, 0}^{0} \\
(\mathrm{BrOOOOF})\end{array}$} \\
\hline & НОН & $\mathrm{HOBr}$ & НООН & HOF & $\begin{array}{c}\text { BrOOOOF } \\
\text { c }\left(\mathrm{C}_{1},{ }^{1} \mathrm{~A}\right)\end{array}$ & & \\
\hline BHLYP & -76.40988 & -2649.83736 & -151.51249 & -175.50871 & -2974.29785 & 38.66 & 63.28 \\
\hline B3P86 & -76.62947 & -2650.88786 & -151.91207 & -175.90318 & -2976.08610 & 52.80 & 49.14 \\
\hline B3LYP & -76.45274 & -2649.92233 & -151.59656 & -175.59224 & -2974.56896 & 51.98 & 49.96 \\
\hline BP86 & -76.45287 & -2650.17532 & -151.60450 & -175.59915 & -2974.89229 & 76.51 & 24.74 \\
\hline BLYP & -76.43467 & -2649.91747 & -151.57898 & -175.58312 & -2974.61332 & 75.55 & 25.70 \\
\hline
\end{tabular}

Table 6. Heats of formation $\left(\mathrm{kcal} \mathrm{mol}^{-1}\right)$ of $\mathrm{BrO}_{4} \mathrm{~F}$ isomers.

\begin{tabular}{lccccccc}
\hline & a & b & c & d & e & f & g \\
\hline BHLYP & 30.88 & 81.19 & 63.28 & 62.65 & 63.28 & 62.65 & 109.51 \\
B3P86 & 20.30 & 46.44 & 49.14 & 49.51 & 83.45 & 61.30 & 112.77 \\
B3LYP & 18.81 & 46.49 & 49.96 & 50.00 & 82.94 & 64.11 & 115.72 \\
BP86 & $---{ }^{a}$ & 15.41 & 24.74 & 25.01 & 56.76 & 37.36 & 112.59 \\
BLYP & - -- $^{a}$ & 16.23 & 25.70 & 25.71 & 56.54 & 39.95 & 116.00 \\
\hline a At pure DFT methods (BP86 and BLYP), the triplet state of $\mathrm{F}-\mathrm{Br} \ldots \mathrm{O}_{2} \ldots \mathrm{O}_{2}$ \\
dissociated to BrF and $\mathrm{O}_{2}$.
\end{tabular}

For these complexes of Lewis acid $(\mathrm{BrF})$ and base (lone pair $\mathrm{O}_{\mathrm{m}}$ chains), we treated as a local version of the hard and soft acid base (HSAB) principle [40]. The DFT-based local reactivity descriptors such as the global or local softness or hardness, condensed Fukui functions can be used to explain the stability of isomers. The predicted global hardness $(\eta)$ and softness $(G S)$ for the minimum- 
energy $\mathrm{BrO}_{4} \mathrm{~F}$ structures (a, $\mathbf{b}, \mathbf{c}, \mathbf{d}, \mathbf{e}, \mathbf{f}$, and $\mathbf{g}$ isomers) with five DFT methods are shown in Tables 7 and 8 respectively. The local softness $\left(\mathrm{S}_{\mathrm{x}}{ }^{+}\right.$and $\left.\mathrm{S}_{\mathrm{x}}{ }^{-}\right)$, and ratios of them $\left(\mathrm{S}_{\mathrm{x}}{ }^{-} / \mathrm{S}_{\mathrm{x}}{ }^{+}\right)$for the minimum $\mathrm{BrO}_{4} \mathrm{~F}$ structures (a, b, c, d, e, f, and $\mathbf{g}$ isomers) at the B3LYP/DZP++ level are tabulated in Table 9. According the Pearson's PMH suggestion [41], the $\mathrm{Br}(\mathrm{VII})$ structure (g) $\mathrm{FBrO}_{3} \ldots \mathrm{O}$ in this work has the largest global hardness (Table 7), and smallest global softness (Table 8), thus triplet state $\mathrm{FBrO}_{3} \ldots \mathrm{O}$ structure is the most stable isomer. For $\mathrm{BrO}_{4} \mathrm{~F}$ isomers, the maximum value (from 5.1 to 8.2, at B3LYP/DZZ++ level, as 8.2) of global hardness (Table 7) set in the highest symmetric Br(VII) $\mathrm{FBrO}_{3} \ldots \mathrm{O}$ structure (g), whereas the minimum value (from 2.9 to 3.2) of hardness assign to singlet BrOO...OOF isomer (b), inversely, the isomers (g) or (b) possesses the smallest or largest global softness (Table 8), respectively, namely, from 0.06 to 1.0 , or from 0.16 to 0.17 . For $\mathrm{Br}$ in the different isomers presents almost either the largest or smallest $\mathrm{S}_{\mathrm{x}}{ }^{-} / \mathrm{S}_{\mathrm{x}}{ }^{+}$values (Table 9), corresponding to different bonds stabilities. An important finding from this investigation is that $\mathrm{Br}$ may reveal the flexibility in which the bromine atom shares valence electrons and orbitals to form a variety of hypervalent species, even the extend hypervalent system.

Table 7. Global hardness Approximated as: $\eta=1 / 2(I E-E A)$ of $\mathrm{BrO}_{4} \mathrm{~F}$ isomers.

\begin{tabular}{lccccccc}
\hline & a & b & c & d & e & f & g \\
\hline BHLYP & 4.7887 & 3.0850 & 4.9960 & 4.9734 & 4.1040 & 4.6173 & 6.0183 \\
B3P86 & 4.1283 & 3.1846 & 4.3096 & 4.2192 & 3.7400 & 4.0823 & 5.0613 \\
B3LYP & 4.1415 & 2.8950 & 4.1995 & 4.1144 & 3.5957 & 3.9306 & 8.2104 \\
BP86 & $--^{a}$ & 3.1694 & 4.8052 & 3.6550 & 3.5028 & 3.8778 & 6.9996 \\
BLYP & - -- $^{\mathrm{a}}$ & 3.1108 & 3.6132 & 3.5698 & 3.4107 & 3.7634 & 7.0271 \\
\hline
\end{tabular}

${ }^{\mathrm{b}}$ At pure DFT methods (BP86 and BLYP), the triplet state of $\mathrm{F}-\mathrm{Br} \ldots \mathrm{O}_{2} \ldots \mathrm{O}_{2}$ dissociated to $\mathrm{BrF}$ and $\mathrm{O}_{2}$.

Table 8. Global softness approximated as: $G S=1 /(2 \eta)=1 /(I E-E A)$ of $\mathrm{BrO}_{4} \mathrm{~F}$ isomers.

\begin{tabular}{lccccccc}
\hline & a & b & c & d & e & f & g \\
\hline BHLYP & 0.1044 & 0.1621 & 0.1001 & 0.1005 & 0.1218 & 0.1083 & 0.0831 \\
B3P86 & 0.1211 & 0.1570 & 0.1160 & 0.1185 & 0.1337 & 0.1225 & 0.0988 \\
B3LYP & 0.1207 & 0.1727 & 0.1191 & 0.1215 & 0.1391 & 0.1272 & 0.0609 \\
BP86 & $--^{\text {a }}$ & 0.1578 & 0.1041 & 0.1368 & 0.1427 & 0.1290 & 0.0714 \\
BLYP & $--^{\text {a }}$ & 0.1607 & 0.1384 & 0.1401 & 0.1466 & 0.1329 & 0.0712 \\
\hline
\end{tabular}

${ }^{\mathrm{b}}$ At pure DFT methods (BP86 and BLYP), the triplet state of $\mathrm{F}-\mathrm{Br} \ldots \mathrm{O}_{2} \ldots \mathrm{O}_{2}$ dissociated to $\mathrm{BrF}$ and $\mathrm{O}_{2}$. 
Table 9. Predicted global softness (GS), local softness $\left(\mathrm{S}_{\mathrm{x}}{ }^{+}\right.$and $\left.\mathrm{S}_{\mathrm{x}}^{-}\right)$, and ratio of them for the $\mathrm{BrO}_{4} \mathrm{~F}(\mathbf{a}, \mathbf{b}, \mathbf{c}, \mathbf{d}, \mathbf{e}, \mathbf{f}$, and $\mathbf{g})$ isomers.

\begin{tabular}{|c|c|c|c|c|c|c|}
\hline Species & GS & atom & $\mathbf{S}_{\mathbf{x}}^{+}$ & $\mathbf{S}_{\mathbf{x}}^{-}$ & $\mathbf{S}_{\mathbf{x}}{ }^{0}$ & $\mathbf{S}_{\mathbf{x}}^{-} / \mathbf{S}_{\mathbf{x}}{ }^{+}$ \\
\hline \multirow[t]{6}{*}{$\mathbf{a}$} & 0.1207 & $\mathrm{Br} 1$ & 0.0139 & 0.0524 & 0.0332 & 3.7739 \\
\hline & & F2 & 0.0091 & 0.0173 & 0.0132 & 1.8959 \\
\hline & & $\mathrm{O} 3$ & 0.0321 & 0.0097 & 0.0209 & 0.3024 \\
\hline & & $\mathrm{O} 4$ & 0.0191 & 0.0096 & 0.0144 & 0.5014 \\
\hline & & O5 & 0.0136 & 0.0114 & 0.0125 & 0.8398 \\
\hline & & O6 & 0.0329 & 0.0203 & 0.0266 & 0.6171 \\
\hline \multirow[t]{6}{*}{ b } & 0.1727 & $\mathrm{Br} 1$ & 0.0329 & 0.0695 & 0.0516 & 2.1350 \\
\hline & & F2 & 0.0152 & 0.0248 & 0.0202 & 1.6460 \\
\hline & & $\mathrm{O} 3$ & 0.0391 & 0.0240 & 0.0317 & 0.6206 \\
\hline & & $\mathrm{O} 4$ & 0.0303 & 0.0089 & 0.0196 & 0.2964 \\
\hline & & O5 & 0.0188 & 0.0077 & 0.0133 & 0.4142 \\
\hline & & O6 & 0.0363 & 0.0359 & 0.0363 & 0.9989 \\
\hline \multirow[t]{6}{*}{ c } & 0.1191 & $\mathrm{Br} 1$ & 0.0758 & 0.0529 & 0.0643 & 0.6976 \\
\hline & & $\mathrm{O} 2$ & 0.0025 & 0.0143 & 0.0084 & 5.6573 \\
\hline & & $\mathrm{O} 3$ & 0.0120 & 0.0102 & 0.0111 & 0.8584 \\
\hline & & O4 & 0.0067 & 0.0100 & 0.0083 & 1.5076 \\
\hline & & O5 & 0.0122 & 0.0178 & 0.0150 & 1.4537 \\
\hline & & F6 & 0.0100 & 0.0139 & 0.0119 & 1.4003 \\
\hline \multirow[t]{6}{*}{ d } & 0.1215 & $\mathrm{Br} 1$ & 0.0771 & 0.0540 & 0.0656 & 0.7007 \\
\hline & & $\mathrm{O} 2$ & 0.0021 & 0.0144 & 0.0083 & 6.7342 \\
\hline & & $\mathrm{O} 3$ & 0.0116 & 0.0102 & 0.0109 & 0.8789 \\
\hline & & O4 & 0.0064 & 0.0094 & 0.0079 & 1.4708 \\
\hline & & O5 & 0.0113 & 0.0165 & 0.0139 & 1.4627 \\
\hline & & F6 & 0.0131 & 0.0170 & 0.0150 & 1.3029 \\
\hline \multirow[t]{6}{*}{$\mathbf{e}$} & 0.1391 & $\mathrm{Br} 1$ & 0.0451 & 0.0634 & 0.0542 & 1.4053 \\
\hline & & $\mathrm{O} 2$ & 0.0212 & 0.0243 & 0.0228 & 1.1459 \\
\hline & & $\mathrm{O} 3$ & 0.0057 & 0.0027 & 0.0042 & 0.4809 \\
\hline & & $\mathrm{O} 4$ & 0.0294 & 0.0225 & 0.0260 & 0.7664 \\
\hline & & O5 & 0.0243 & 0.0137 & 0.0190 & 0.5635 \\
\hline & & F6 & 0.0133 & 0.0124 & 0.0128 & 0.9313 \\
\hline \multirow[t]{6}{*}{ f } & 0.1272 & $\mathrm{Br} 1$ & 0.0343 & 0.0174 & 0.0259 & 0.5084 \\
\hline & & $\mathrm{O} 2$ & 0.0242 & 0.0234 & 0.0238 & 0.9666 \\
\hline & & $\mathrm{O} 3$ & 0.0256 & 0.0341 & 0.0298 & 1.3307 \\
\hline & & O4 & 0.0164 & 0.0168 & 0.0166 & 1.0268 \\
\hline & & O5 & 0.0122 & 0.0179 & 0.0150 & 1.4651 \\
\hline & & F6 & 0.0146 & 0.0176 & 0.0161 & 1.2120 \\
\hline \multirow[t]{4}{*}{ g } & 0.0609 & $\mathrm{Br} 1$ & 0.0094 & -0.0046 & 0.0024 & -0.4827 \\
\hline & & F2 & 0.0072 & 0.0069 & 0.0070 & 0.9580 \\
\hline & & $\mathrm{O} 3$ & 0.0065 & -0.0008 & 0.0029 & -0.1171 \\
\hline & & $\mathrm{O} 4$ & 0.0249 & 0.0608 & 0.0429 & 2.4447 \\
\hline
\end{tabular}




\section{Conclusions}

The structures, electron affinities and bond dissociation energies of $\mathrm{BrO}_{4} \mathrm{~F} / \mathrm{BrO}_{4} \mathrm{~F}^{-}$species have been studied with five DFT methods. The B3LYP method is the most reliable method for predicting the geometry and electron affinities for this ternary species. The $\mathrm{EA}_{\mathrm{ad}}$ value predicted by the B3LYP method is $4.52 \mathrm{eV}$ for $\mathrm{BrO}_{4} \mathrm{~F}$. The $\mathrm{EA}_{\mathrm{ad}}$ values for $\mathrm{OBrF}$ [34], $\mathrm{FBrOO}$, and $\mathrm{FBrOOO}$ [35] species are 3.64, 5.83 and $4.43 \mathrm{eV}$, respectively. and close to those of other interhalogen compounds, such as $\mathrm{BrCIF}_{\mathrm{n}}$ and $\mathrm{BrF}_{\mathrm{n}}[37,56]$. Those with odd $\mathrm{n}\left(\mathrm{n}=1\right.$ and 3, closed shell) have smaller EA $\mathrm{A}_{\mathrm{ad}}$ than those of even $n(n=2$ and 4$)$ species, which are open-shell triplet state. These substantial electron affinities suggest that the corresponding anion may have the lifetimes as independent species under atmospheric conditions.

Similar to the case of the electron affinities, the hybrid DFT methods especial BHLYP predict the discrepant values of bond dissociation energies for $\mathrm{BrO}_{4} \mathrm{~F} / \mathrm{BrO}_{4} \mathrm{~F}^{-}$dissociation reactions and relative energies from two pure DFT methods, demonstrating that this system is a challenge for DFT methods.

Although the $\mathrm{FBr}-\mathrm{O}_{2}-\mathrm{O}_{2} /\left(\mathrm{FBr}-\mathrm{O}_{2}-\mathrm{O}_{2}\right)^{-}$chain structures have been found to be the most stable isomers, yet there is no workable reaction mechanism for the formation of these species considering only $\mathrm{BrF}$ or $\mathrm{BrF}^{-}, \mathrm{BrO}$ and $\mathrm{O}_{2}$ or $\mathrm{O}_{2}{ }^{-}$as starting materials. According recently report on bromine (VII) $\mathrm{BrO}_{3} \mathrm{~F}_{2}^{-}$anion [31], we conclude that the $\mathrm{Br}(\mathrm{VII})$ structure, $\mathrm{FBrO}_{3} \ldots \mathrm{O}\left(\mathrm{g}: \mathrm{C}_{3 \mathrm{v}},{ }^{3} \mathrm{~A}_{1}\right)$ are the most likely structure for neutral $\mathrm{BrO}_{4} \mathrm{~F}$, and the $\mathrm{BrO}_{4} \mathrm{~F}^{-}$may have $\mathrm{Br}(\mathrm{V})\left(\mathrm{FO} . . \mathrm{BrO}_{3}\right)^{-}$(ac: $\left.{ }^{2} \mathrm{~A}^{\prime}\right)$ complex structure. The DFT-based local reactivity descriptors such as the global or local softness or hardness, condensed Fukui functions can demonstrate this suggestion.

The DFT methods are able to describe the electronic structure of these systems with accuracies comparable to traditional correlated molecular orbital methods at a decreased computational cost. Furthermore these DFT-based local descriptors techniques are observed to assign more bonding character to the $\mathrm{BrO}_{4} \mathrm{~F}$ Lewis system.

\section{Acknowledgements}

This work was supported by the China Sustentation Fund of Scientific and Technological Development Project of Beijing Municipal Education Commission (No. KM200810017007). We thank the editors and reviewers for their time, patience and help.

\section{References and Notes}

1. Chatterjee, A.; Iwasaki, T.; Hayashi, H.; Ebina, T.; Torri, K. Electronic and structural properties of montmorillonite - a quantum chemical study. J.Mol. Catal. 1998, 136, 195-202.

2. Chatterjee, A.; Ebina, T.; Mizukami, F. Effects of Water on the structure and bonding of resorcinol in the interlayer of montmorillonite nanocomposite: A periodic first principle study. $J$. Phys. Chem. B 2005, 109, 7306-7313.

3. Chatterjee, A.; Iwasaki, T.; Ebina, T.; Miyamoto, A. A DFT study on clay-cation-water interaction in montmorillonite and beidellite. Comput. Mater. Sci. 1999, 14, 119-124. 
4. Chatterjee, A.; Iwasaki, T.; Ebina, T. A novel method to correlate layer charge and the catalytic activity of 2:1 dioctahedral smectite clays in terms of binding the interlayer cation surrounded by monohydrate. J. Phys. Chem A 2000, 104, 8216-8223.

5. Chatterjee, A.; Ebina, T.; Onodera, Y.; Mizukami, F. Effect of exchangeable cation on the swelling property of 2:1 dioctahedral smectite-A periodic first principle study. J.Chem. Phys. 2004, 120, 3414-3422.

6. Chatterjee, A.; Iwasaki, T.; Ebina, T. Sorbent for dioxins and furans: reactivity index study. $J$. Phys. Chem. A 2002, 106, 641-648.

7. Chatterjee, A.; Niwa, S.; Mizukami, F. Structure and property correlation for Ag deposition on $\alpha$ $\mathrm{Al}_{2} \mathrm{O}_{3}$ - a first principle study. J. Mol. Graph. Model. 2005, 23, 447-456.

8. Szöllösi, G.; Chatterjee, A.; Forgó, P.; Bartók, M.; Mizukami, F. Structure-property relationship in py-hexahydrocinchonidine diastereomers: ab Initio and NMR study. J. Phys. Chem. A 2005, 109, 860-868.

9. Parr, R.G. How I came about working in conceptual DFT. In Chemical Reactivity Theory: $A$ Density Functional Theory View; Chattaraj, P.K., Ed.; Taylor \& Francis Group: London, UK, 2009.

10. Parr, R.G.; Yang, W. Density functional approach to the frontier-electron theory of chemical reactivity. J. Am. Chem. Soc. 1984, 106, 4049-4050.

11. Geerlings, P.; De Proft, F.; Langenaekar, W. Conceptual density functional theory. J. Chem. Rev. 2003, 103, 1793-1873.

12. Nguyen, L.T.; Le, T.N.; De Proft, F.; Chandra, A.K.; Langenaeker,W.; Nguyen, M.T.; Geerlings, P. Mechanism of $[2+1]$ cycloadditions of hydrogen isocyanide to alkynes: molecular orbital and density functional theory study. J. Am. Chem. Soc. 1999, 121, 5992-6001.

13. Langenaeker, W.; De Proft, F.; Geerlings, P. Ab initio and density functional theory study of the geometry and reactivity of benzyne, 3-fluorobenzyne, 4-fluorobenzyne, and 4,5-Didehydropyrimidine. J. Phys. Chem. A 1998, 102, 5944-5950.

14. Chandra, A.K.; Geerlings, P.; Nguyen, M.T. On the asynchronism of isocyanide addition to dipolarophiles: Application of local softness. J. Org. Chem. 1997, 62, 6419.

15. Sivanesan, D.; Amutha, R.; Subramanian, V.; Nair, B.U.; Ramaswami, T. Assessment of the importance of the solvent in the calculation of condensed Fukui function: a self-consistent reaction field calculation study. Chem. Phys. Lett. 1999, 308, 223-228.

16. Yang, W.; Mortier, M.J. The use of global and local molecular parameters for the analysis of the gas-phase basicity of amines. J. Am. Chem. Soc. 1986, 108, 5708-5711.

17. Hebestreit, K.; Stutz, J.; Rosen, D.; Matveiv, V.; Peleg, M.; Luria M.; Platt, U. DOAS Measurements of tropospheric bromine oxide in mid-latitudes. Science 1999, 283, 55-57.

18. Karton, A.; Parthiban, S.; Martin, J.M.L. Post-CCSD(T) ab initio thermochemistry of halogen Oxides and related hydrides XOX, XOOX, HOX, XO, and $\mathrm{HXO}(\mathrm{X}=\mathrm{F}, \mathrm{Cl})$, and evaluation of DFT methods for these systems. J. Phys. Chem. A 2009, 113, 4802-4816.

19. Matus, M.H.; Nguyen, M.T.; Dixon, D.A.; Peterson, K.A.; Francisco, J.S. $\mathrm{ClClO}_{2}$ is the most stable isomer of $\mathrm{Cl}_{2} \mathrm{O}_{2}$. Accurate coupled cluster energetics and electronic spectra of $\mathrm{Cl}_{2} \mathrm{O}_{2}$ isomers. J. Phys. Chem. A 2009, 112, 9623-9627. 
20. Li, Z.; Francisco, J.S. A density functional study of structure and heat of formation for $\mathrm{Br}_{2} \mathrm{O}_{4}$ and $\mathrm{Br}_{2} \mathrm{O}_{5}$. Chem. Phys. Lett. 2002, 354, 109-119.

21. Xie, Y.; Schaefer, H.F.; Wang, Y.; Fu, X.; Liu, R. Electron affinities of the bromine oxides $\mathrm{BrO}_{\mathrm{n}}$, $\mathrm{n}=1-4$. Mol. Phys. 2000, 98, 879-890.

22. Martin, J.M.L. Heats of formation of perchloric acid, $\mathrm{HClO} 4$, and perchloric anhydride, $\mathrm{Cl}_{2} \mathrm{O}_{7}$. Probing the limits of W1 and W2 theory. J. Mol. Struct.: THEOCHEM 2006, 771, 19-26.

23. Ju, X.H.; Wang, Z.Y.; Yan, X.F.; Xiao, H.M. Density functional theory studies on dioxygen difluoride and other fluorine/oxygen binary compounds: Availability and shortcoming. J. Mol. Struct: : THEOCHEM 2007, 804, 95-100.

24. Prascher, B.P.; Wilson, A.K. A computational study of dihalogen-1-dichalcogenides: XAAX (X = F, Cl, Br; A = S, Se). J. Mol. Struct: THEOCHEM 2007, 814, 1-10.

25. Feller, D.; Dixon, D.A. Coupled cluster theory and multireference configuration interaction study of FO, $\mathrm{F}_{2} \mathrm{O}, \mathrm{FO}_{2}$, and FOOF. J. Phys. Chem. A 2003, 107, 9641-9651.

26. Kraka, E.; He, Y.; Cremer, D. Quantum chemical descriptions of FOOF: the unsolved problem of predicting its equilibrium geometry. J. Phys. Chem. A 2001, 105, 3269-3276.

27. Johnson, G.K.; O'Hare, P.A.G.; Appelman, E.H. Thermodynamic properties of perbromyl fluoride $\left(\mathrm{BrO}_{3} \mathrm{~F}\right)$. Inorg. Chem. 1972, 11, 800-802.

28. Appelman, E.H.; Beagley, B.; Cruickshank, D.W.J.; Foord, A.; Rustad, S.; Ulbrecht, V. An electron-diffraction study of the molecular structure of gaseous perbromyl fluoride and calculation of its force field and vibrational amplitudes. J. Mol. Struct.: THEOCHEM 1976, 35,139-148.

29. Gillespie, R.J.; Spekkens, P. Preparation and characterization of potassiumdifluorodioxobromate and tetrafluoro-oxobromate. J. Chem. Soc. Dalton Trans. 1976, 2391-2396.

30. Christe, K.O.; Curtis, E.C.; Bougon R. Bromine trifluoride oxide. Vibrational spectrum, force constants and thermodynamic properties. Inorg. Chem. 1978, 17, 1533-1539.

31. Lehmann, J.F.; Schrobilgen, G.J. Synthesis and characterization of salts containing the $\mathrm{BrO}_{3} \mathrm{~F}_{2}^{-}$ anion; A rare example of a bromine (VII) species. J. Am. Chem. Soc. 2005, 127, 9416-9427.

32. Lehmann, J.F.; Riedel, S.; Schrobilgen, G.J. Behavior of $\mathrm{BrO}_{3} \mathrm{~F}$ and $\mathrm{ClO}_{3} \mathrm{~F}$ Toward strong lewis acids and the characterization of $\left[\mathrm{XO}_{2}\right]\left[\mathrm{SbF}_{6}\right](\mathrm{X}=\mathrm{Cl}, \mathrm{Br})$ by single cCrystal X-ray diffraction, raman spectroscopy, and computational methods. Inorg. Chem. 2008, 47, 8343-8356.

33. Francisco, J.S. Structure, vibrational spectra and energetics of $\mathrm{OBrO}^{+}$. Chem. Phys. Lett. 1998, 288, 307-310.

34. Gong, L.; Li, Q.; Xie, Y.; Schaefer, H.F. Novel bromine oxyfluorides: Structures, thermochemistry and electron affinities of $\mathrm{BrOF}_{\mathrm{n}} / \mathrm{BrOF}_{\mathrm{n}}^{-}(\mathrm{n}=1-5)$. Mol. Phys. 2005, 103, 1995-2008.

35. Li, S.; Gong, L.; Wu, X.; Guo, W. Structures and electron affinities of $\mathrm{BrO}_{2} \mathrm{~F}$ and $\mathrm{BrO}_{3} \mathrm{~F}$. Chem. Phys. Lett. 2007, 439, 395-401.

36. Pak, C.; Xie, Y.; Schaefer, H.F. Electron affinities of the dibromine oxides: $\mathrm{Br}_{2} \mathrm{O}_{\mathrm{n}}(\mathrm{n}=0-4)$. Mol. Phys. 2003, 101, 211-225.

37. Ignatyev, I.S.; Schaefer, H.F. Bromine halides: The neutral molecules $\operatorname{BrClF}_{\mathrm{n}}(\mathrm{n}=1-5)$ and their anions structures, energetics, and electron affinities. J. Am. Chem. Soc. 1999, 121, 6904-6910. 
38. Xu, W.; Cheng, S.; Lu, S.X. Structures, vibrational frequencies, and electron affinities of $\mathrm{SF}_{5} \mathrm{O}_{\mathrm{n}} / \mathrm{SF}_{5} \mathrm{O}_{\mathrm{n}}^{-}(\mathrm{n}=1-3)$. J. Mol. Struct.: THEOCHEM 2009, 900, 77-83.

39. Rienstra-Kiracofe, J.C.; Tschumper,G.S.; Schaefer, H.F.; Nandi, S.; Ellison, G.B. Atomic and molecular electron affinities: Photoelectron experiments and theoretical computations. Chem. Rev. 2002, 102, 231-282.

40. Parr, R.G.; Pearson, R.G. Absolute Hardness: Companion parameter to absolute electronegativity. J. Am. Chem. Soc. 1983, 105, 7512-7516.

41. Pearson, R.G. Recent advances in the concept of hard and soft acids and bases. J. Chem. Educ. 1987, 64, 561-567.

42. Becke, A.D. A new mixing of Hartree-Fock and local density-functional theories J. Chem. Phys. 1993, 98, 1372. BHandHLYP method in the Gaussian programs has $0.5 * \operatorname{Ex}(\mathrm{LSDA})+0.5 * \operatorname{Ex}(\mathrm{HF})+0.5 *$ Delta-Ex(B88) $+\mathrm{Ec}(\mathrm{LYP})$ formula, which is not precisely the formulation proposed in his paper.

43. Lee, C.; Yang, W.; Parr, R.G. Development of the Colle-Salvetti correlation-energy formula into a functional of the electron density. Phys. Rev. B 1988, 37, 785-789.

44. Becke. A.D. Density-functional thermochemistry. III. The role of exact exchange. J. Chem. Phys. 1993, 98, 5648-5652.

45. Perdew, J.P. Density-functional approximation for the correlation energy of the inhomogeneous electron gas. Phys. Rev. B 1986, 33, 8822-8824.

46. Becke, A.D. Density-functional exchange-energy approximation with correct asymptotic behavior. Phys. Rev. A 1988, 38, 3098-3100.

47. Schafer, A.; Horn, H.; Ahlrichs, R. Br Basis sets. Fully optimized contracted Gaussian basis sets for atoms Li to Kr. J. Chem. Phys. 1992, 97, 2571-2577.

48. Huzinaga, S. F and O Basis setsGaussian-Type Functions for Polyatomic Systems I. J. Chem. Phys. 1965, 42, 1293-1302.

49. Dunning, T.H. Gaussian Basis Functions for Use in Molecular Calculations. I. Contraction of (9s5p) Atomic Basis Sets for the First-Row Atoms F and O Basis sets. J. Chem. Phys. 1970, 53, 2823-2833.

50. Frisch, M.J.; Trucks, G.W.; Schlegel, H.B.; Scuseria, G.E.; Robb, M.A.; Cheeseman, J.R., Jr.; Montgomery, J.A.; Vreven, T.; Kudin, K.N.; Burant, J.C.; Millam, J.M.; Iyengar, S.S.; Tomasi, J.; Barone, V.; Mennucci, B.; Cossi, M.; Scalmani, G.; Rega, N.; Petersson, G.A.; Nakatsuji, H.; Hada, M.; Ehara, M.; Toyota, K.; Fukuda, R.; Hasegawa, J.; Ishida, M.; Nakajima, T.; Honda, Y.; Kitao, O.; Nakai, H.; Klene, M.; Li, X.; Knox, J.E.; Hratchian, H.P.; Cross, J.B.; Adamo, C.; Jaramillo, J.; Gomperts, R.; Stratmann, R.E.; Yazyev, O.; Austin, A.J.; Cammi, R.; Pomelli, C.; Ochterski, J.W.; Ayala, P.Y.; Morokuma, K.; Voth, G.A.; Salvador, P.; Dannenberg, J.J.; Zakrzewski, V.G.; Dapprich, S.; Daniels, A.D.; Strain, M.C.; Farkas, O.; Malick, D.K.; Rabuck, A.D.; Raghavachari, K.; Foresman, J.B.; Ortiz, J.V.; Cui, Q.; Baboul, A.G.; Clifford, S.; Cioslowski, J.; Stefanov, B.B.; Liu, G.; Liashenko, A.; Piskorz, P.; Komaromi, I.; Martin, R.L.; Fox, D.J.; Keith, T.; Al-Laham, M.A.; Peng, C.Y.; Nanayakkara, A.; Challacombe, M.; Gill, P.M.W.; Johnson, B.; Chen, W.; Wong, M.W.; Gonzalez, C.; Pople, J.A. Gaussian 03: IA32WG03RevC 02 12-Jun-2004. Gaussian, Inc.: Wallingford, CT, USA, 2004. 
51. Reed, A.E.; Curtiss, L.A.; Weinhold, F. Intermolecular interactions from a natural bond orbital, donor-acceptor viewpoint. Chem. Rev. 1988, 88, 899-926.

52. Boys, S.F.; Bernardi, F. The calculation of small molecular interactions by the differences of separate total energies. Some procedures with reduced errors. Mol. Phys., 1970, 19, 553-557.

53. Orita, H.; Itoh, N.; Inada, Y. A comparison of CO adsorption on $\mathrm{Pt}(211), \mathrm{Ni}(211)$, and $\mathrm{Pd}(211)$ surfaces using density functional theory. Surf. Sci. 2004, 571, 161-172.

54. Boese, A.D.; Martin, J.M.L.; Handy, N.C. The role of the basis set: Assessing density functional theory. J. Chem. Phys. 2003, 119, 3005-3015.

55. Tschumper, G.S.; Schaefer, H.F., III Predicting electron affinities with density functional theory: Some positive results for negative ions. J. Chem. Phys. 1997, 107, 2529-2541.

56. Pak, C.; Xie, Y.; Van Huis, T.J.; Schaefer, H.F. Electron affinities of the bromine fluorides, $\mathrm{BrF}_{\mathrm{n}}$ (n=1-7). J. Am. chem. Soc. 1998, 120, 11115-11121.

57. Roos, B.J. In Ab Initio Methods in Quantum Chemistry; Lawley, K.P., Ed.; John Wiley \& Sons: New York, USA, 1987; pp. 399-445.

58. Guha, S.; Francisco, J.S. Structures, vibrational spectra, and relative energetics of $\mathrm{CH}_{3} \mathrm{BrO}_{3}$ isomers. J. Phys. Chem. A 2000, 104, 3239-3245.

59. Chase, M.W.; Davies, C.A.; Downey, J.R.; Frurip, D.J.; McDonald, R.A.; Syverud, A.N. NISTJANAF Thermochemical Tables. J. Phys. Chem. Ref. Data 1985, 1, 146-147.

60. Ruscic, R.; Berkowitz, J. Experiment determination of $\Delta \mathrm{H}_{\mathrm{f}}{ }^{\theta}(\mathrm{HOBr})$ and ionization potentials (HOBr): Implications for the corresponding properties of HOI. J. Chem. Phys. 1994, 101, 7795-7803.

61. Chase, M.W.; Davies, C.A.; Downey, J.R.; Frurip, D.J.; McDonald, R.A.; Syverud, A.N. JANAF Thermochemical Tables, 3rd ed. J. Phys. Chem. Ref. Data 1985, 14 (Suppl. 1), 8-9.

(C) 2009 by the authors; licensee Molecular Diversity Preservation International, Basel, Switzerland. This article is an open-access article distributed under the terms and conditions of the Creative Commons Attribution license (http://creativecommons.org/licenses/by/3.0/). 